NBER WORKING PAPER SERIES

\author{
WHY DIDN'T FRANCE FOLLOW THE \\ BRITISH STABILIZATION AFTER WORLD WAR ONE? \\ Michael D. Bordo \\ Pierre-Cyrille Hautcoeur \\ Working Paper 9860 \\ http://www.nber.org/papers/w9860
}
NATIONAL BUREAU OF ECONOMIC RESEARCH
1050 Massachusetts Avenue
Cambridge, MA 02138
July 2003

The views expressed herein are those of the authors and not necessarily those of the National Bureau of Economic Research

(C)2003 by Michael D. Bordo and Pierre-Cyrille Hautcoeur. All rights reserved. Short sections of text not to exceed two paragraphs, may be quoted without explicit permission provided that full credit including (C) notice, is given to the source. 
Why didn't France follow the British Stabilization after World War One?

Michael D. Bordo and Pierre-Cyrille Hautcoeur

NBER Working Paper No. 9860

July 2003

JEL No. E63, M4

\begin{abstract}
We show that the size of the public debt, the budget deficit and the monetary overhang made it impossible for France to stabilize its price level and return to the pre-war parity immediately after World War I, even on the anti-keynesian assumption that a stabilization would not have had any negative effects on real income. The reason for the immediate postwar inflation then was not mismanaged policy but a wise choice in the French context. Nevertheless, a stabilization at a devalued franc which would have been substantially higher than the rate achieved by Poincaré in 1926 was historically possible in early 1924, and it would likely have benefited not only France but the entire international monetary system.
\end{abstract}

Michael D. Bordo

Department of Economics

75 Hamilton Street

New Brunswick, NJ 08901

and NBER

bordo@econ.rutgers.edu
Pierre-Cyrille Hautcoeur

Professeur a l'Universite de Paris I

Pantheon-Sorbonne

Chercheur associe au DELTA

Ecole normale superieure

48 bd Jourdan 75014 Paris

pch@delta.ens.fr 


\title{
Why didn't France follow the British Stabilization after World War One? ${ }^{a}$
}

\author{
Michael D. Bordo ${ }^{*}$ \\ Pierre-Cyrille Hautcœur**
}

\section{Introduction}

The standard interpretation of the history of the inter-war period is that Great Britain, by going back to gold at the original parity, made a big mistake because of the drastic and prolonged reduction in output that resulted from the deflationary policy followed to achieve successful resumption (Keynes 1925). This was aggravated by sterling overvaluation in succeeding years, which put the U.K. at a competitive disadvantage and reinforced the deflation's impact on output. By contrast France is generally viewed as having followed a wiser strategy by not returning to the pre-war parity, then by pursuing an inflationary strategy and allowing the franc to depreciate by $80 \%$ before returning to gold at a devalued parity de facto in 1926 , thus avoiding the economic cost of deflation.

The British followed the deflationary route because of the importance attached by the government and the City of London to maintaining credibility in the bond markets. It was generally believed that a restoration of the pre-war parity would allow the City of London to regain its pre-war position as the center of international finance - in modern terms to follow the gold standard contingent rule.

Recent interpretations of the macroeconomic history of Britain reinforce these arguments and cast some doubt on the classic Keynesian story. They first demonstrate the importance of the reputational argument, showing that a country following the gold standard rule gains by paying durably lower interest rates (Bordo and Kydland 1995). They also discuss the reasons for high unemployment: in contrast to those attributing it to deficient aggregate demand (e.g. Thomas,

\footnotetext{
${ }^{a}$ We thank Debajyoti Chakrabarty for helpful research assistance, participants at seminars at U. Carlos III, U. Paris XII, U. Pompeu Fabra, U. de les Illes Balears, at the World Cliometric Society Meetings (Montreal, July 2000) and the Economic History Association Annual Meetings (Philadelphia, September, 2001), Patrice Baubeau, Bertrand Blancheton, Mark Carlson, Olivier Jeanne, Gianni Toniolo, Marc Trachtenberg, Eugene White and especially Pierre Sicsic for useful comments on an earlier version of this paper.

* Rutgers U. and NBER.

${ }^{* *}$ U. of Paris 1 Panthéon-Sorbonne (Matisse) and DELTA (joint research unit CNRS-EHESS-ENS).
} 
1981), they consider that it mostly reflected an increase in labor-market rigidities and high unemployment benefits (Benjamin and Kochin 1979, 1982). Britain's balance of trade problems are also attributed to rigidities in its specialization rather than to the overvaluation of the pound (Maizels 1970 ; Broadberry and Ritschl 1995).

The new classical reinterpretation of the 1920's has not been applied to French macroeconomic history, even if there exist some good reasons to do so: that the French government also believed in the importance of reputation to maintain its borrowing capacity in an unstable world; and that France had also been an important international financial center before 1914 and wished to rebuild that position. So it is not surprising that after World War I many argued that it should follow a policy similar to the British for similar reasons. The costs of the inflationary process from 1914 to 1926 are also well known: a fragile financial system (Bouvier, 1984); leading to insufficiently capitalized firms; a decline in the international position of the French financial market; undervaluation of the franc leading to inadequate specialization subsequently revealed during the 1927-28 post-stabilization crisis (Marseille 1981).

The purpose of this paper is to open the debate by asking why France did not follow the British example in an early deflationary policy and stabilization at the pre-war gold parity. Specifically we ask the following questions: Was it possible for France to follow Britain in 1919 ? What were the reasons or the constraints behind the choice made at the French Ministry of Finance to resist the Banque de France and the public demand for a return to gold at the prewar parity (with the revaluation and the deflation it implied) ? (Blancheton 2000). If the civil servants in the rue de Rivoli, best symbolized by Pierre de Moüy, director of the Mouvement général des fonds (the Treasury), wanted to stabilize the currency without destabilizing the economy, did they succeed or was it possible to stabilize earlier at a lower cost?

In this paper we thus concentrate on the simple question, could France have followed a British-style macroeconomic strategy beginning in 1919, the last point at which French prices were within striking distance of restoring pre-war purchasing power parity with respect to the pound? What was the actual importance of the constraints (budget deficit, public debt, monetary overhang, political instability) that the French government faced in order to implement that strategy?

To answer this question, we simulate a simple model of the French economy in the 1920's. The model captures the effects of deflation and higher taxes on the supply side through the effects via sticky wages on investment and real output. The counterfactual effects of a British-style stabilization policy on fiscal balance is captured by assuming tax increases, conversion of the 
short-term French debt into long-term debt and imposing the paths of British interest rates to calculate debt service costs.

The results of our simulation suggest that even in the most optimistic case (consistent with our supply side model which minimizes most of the short term depressive effects of the stabilization), with superior effects on the real economy than in the observed British pattern, the fiscal outcome would have been dramatic - the debt to GDP ratio would have been much higher than the British level and would have likely been unsustainable. Furthermore, the short term benefits to France of following such a policy in terms of bond market credibility were not that great. After the de facto stabilization, French long-term interest rates declined below British levels within two years. This suggests that undervaluation and commitment to the gold standard were more important ingredients for low interest rates than the credibility that the return to prewar parity gave to Britain (and which was paid for by intrinsic macroeconomic fragility during the 1920s).

By contrast, a stabilization early in 1924, during the first Poincaré government ( which was subsequently replaced by the Cartel des Gauches), would have been much more easily sustainable. This was because the real value of the debt had already been reduced by inflation and the post-war monetary overhang had disappeared with the beginning of flight from the currency. We speculate on the consequences such an earlier successful stabilization might have had at the national and international levels.

$\underline{\text { Section } 2}$ discusses the historical background with the aid of some figures. Section 3 presents the model. Section 4 contains the simulations. Section 5 describes a hypothetical 1924 stabilization. Section 6 concludes.

\section{Historical Perspectives}

During World War I both Britain and France followed expansionary monetary policies to facilitate war finance and their price levels ballooned, almost doubling in Great Britain by 1918 and more than doubling in France. In the U.S., the major wartime supplier and after 1917, ally, prices only increased $70 \%$ (see figure 1$)^{1}$. Although the exchange rates of the two countries were pegged close to the pre-war parity by the exhaustion of their gold reserves and later by U.S. loans, free convertibility had in a de facto sense been suspended in the face of a panoply of controls. Once hostilities ceased and U.S. support ended, the franc plunged (see figure 2) ; only the pound depreciated less than what one might expect given the price levels, something reflecting expectations of rapid stabilization or a return to pre-war parity.

\footnotetext{
${ }^{1}$ For data sources used in this section see the data appendix.
} 
Figure 1: Price level $(1910=100)$

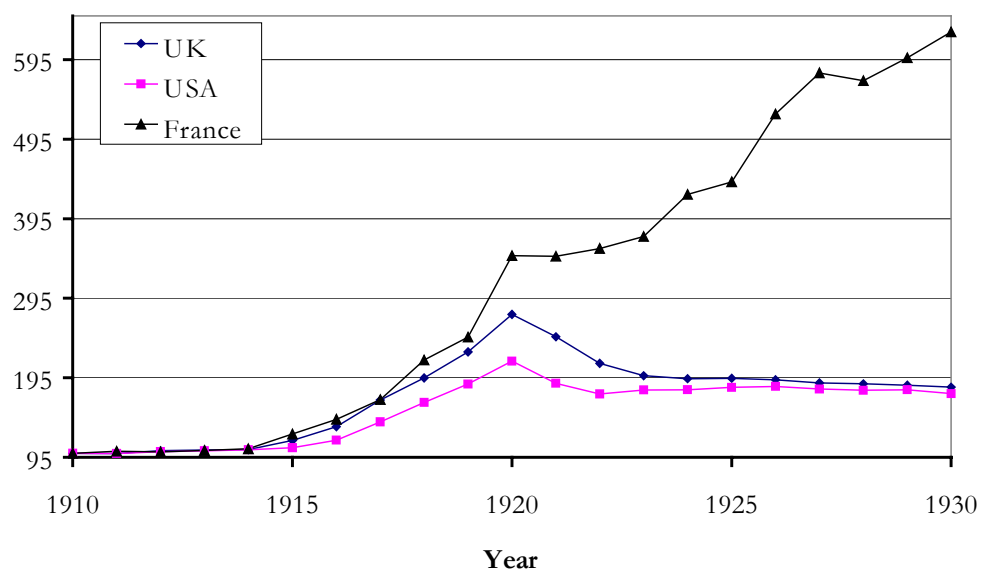

Figure 2: Nominal exchange rate $(1910=100)$

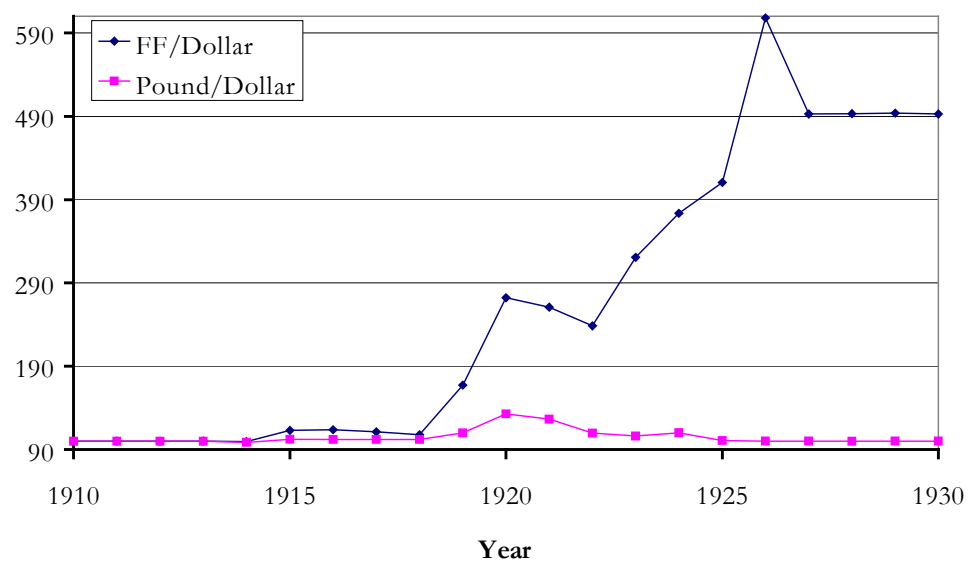

Both countries used a mix of taxes, bond finance, and seigniorage to finance the war. The British were able to raise taxes more than the French and consequently ran smaller budget deficits (for Britain 69\% of expenditures in 1918, for France 80\%, Eichengreen (1992), table 3.1, p. 75). Both countries borrowed considerably and both followed short-term interest rate pegs (figure 3 ) whereby the central banks purchased short-term debt from the government and thereby expanded the monetary base. In both countries the ratio of short-term to long-term debt increased. The French, however, issued more bons de la défense nationale than the British issued Treasury bills. Also France started World War I with a higher national debt relative to Britain and, with larger deficits during the war, ended up with a much higher debt ratio (1.8 versus below 1.4). (see figure 4) 
Figure 3: Short-term interest rates

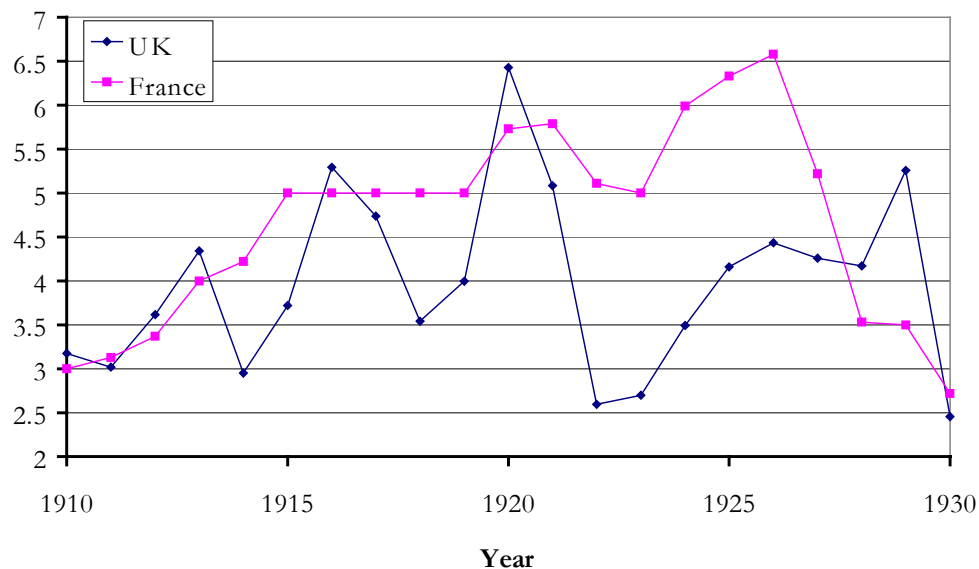

Figure 4: Debt-GDP ratio

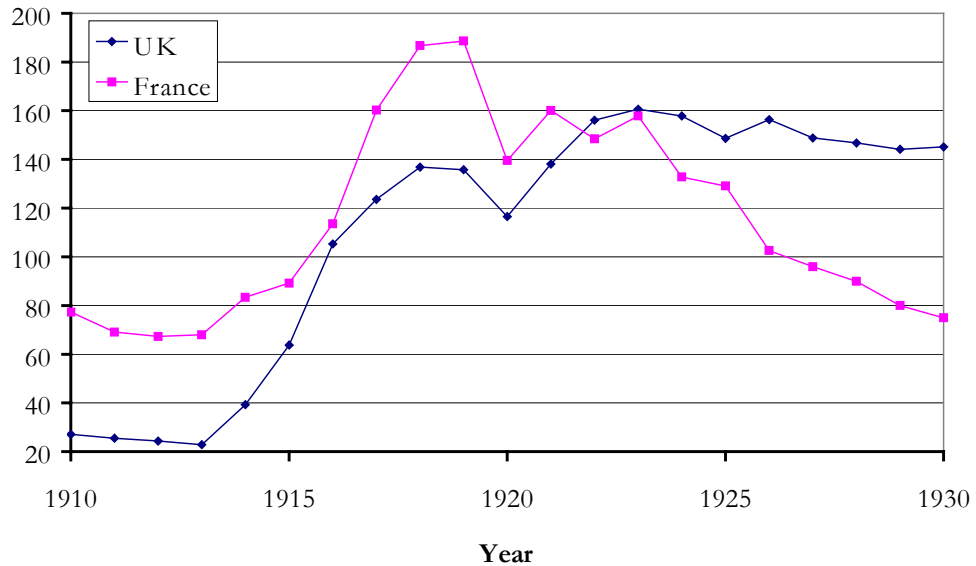

To restore pre-war convertibility, both countries had to reduce their ratios of short-term to long-term debt to prevent a rollover crisis, to restore budget balance and to deflate, in order to restore purchasing power parity with the U.S., the only major country still on the gold standard. France faced a tougher situation than did Britain as it had more inflation to unwind, a greater budget deficit, a higher ratio of short-term to long-term debt and a greater monetary overhang. Yet by early 1919, according to Eichengreen ((1992) p. 73), both countries were within striking distance of restoring parity (the pound was overvalued against the dollar by $10 \%$, the franc by $35 \%)$.

In Britain, although the exchange rate was allowed to float, official circles expressed a strong commitment to resume gold payments at the original parity. The first clear statement was in the Cunliffe Report of 1918, followed in subsequent years by other official documents and most 
clearly by the application of the cuts in government expenditures they recommended (James, 2000). The key argument for resumption at the old parity was the need to maintain credibility. It was widely believed that this would restore the pre-war glory of the City of London (Bayoumi and Bordo 1998). Vociferous opposition to resumption at the original parity before and after the fact was voiced by J.M. Keynes in his tract The Economic Consequences of Mr. Churchill (1925). He was supported by other academics, by labor (but not the official Labor party), and by industry groups. Most of the opposition, however, with the principal exception of Keynes, was centered not on resumption at the old parity per se but on the deflationary policies that were adopted to attain it.

Although the monetary authorities wanted immediate resumption after the war, they were unwilling in 1919 to follow the requisite tight monetary policies. The subsequent boom (which was worldwide) was ended by a very contractionary monetary policy in Britain (in part reflecting the desire to return to the pre-war gold parity), in the US, and in several other countries in early 1920, which led to a serious recession ending in 1921. Thereafter sterling appreciated close to the old parity by December 1922, but the appreciation was reversed and resumption was delayed because of unfavorable events on the Continent (the Germans' refusal to pay reparations and the Belgian-French occupation of the Ruhr (Pollard, 1970)), the unsuccessful attempt by the framers of the Genoa conference to arrange a coordinated international restoration of the gold standard, and the unwillingness of the US to follow an inflationary policy, as the British authorities had expected (Eichengreen, 1992). By early 1924 the exchange rate began a steady appreciation toward parity. The authorities waited until the market had pushed sterling close to $\$ 4.86$ before officially announcing resumption on April 28, 1925 (see figure 2).

During the resumption episode, British money supply contracted sharply between 1919 - 1922 and then leveled off (figure 5), prices fell dramatically in the 1919 - 21 recession and continued to fall through the rest of the decade (figure 1). The British budget deficit declined drastically at the end of the war, reaching a surplus by 1919 (figure 6), as did the ratio of debt to income (figure 4) and the British were able to convert much of their short-term debt to long-term debt. Longterm rates, after rising from 1919 - 21, declined throughout the 1920's reflecting deflation and the restoration of bond market credibility once Britain returned to gold (figure 7). The return to parity likely contributed to a well-known bad economic situation : real GDP and industrial production dropped precipitously (over 10\% below its 1913 level) (see figures 8 and 9). Despite some recovery, they remained below their 1913 levels until 1925 and 1929 respectively. Unemployment also shot up dramatically after 1919 to over $11 \%$ of the labor force. Despite a 
subsequent fall, it was never below $6.5 \%$ for the rest of the decade (figure 10). Accompanying the rise in unemployment was a rise in real wages (figure 11).

Figure 5: Money growth (\%)

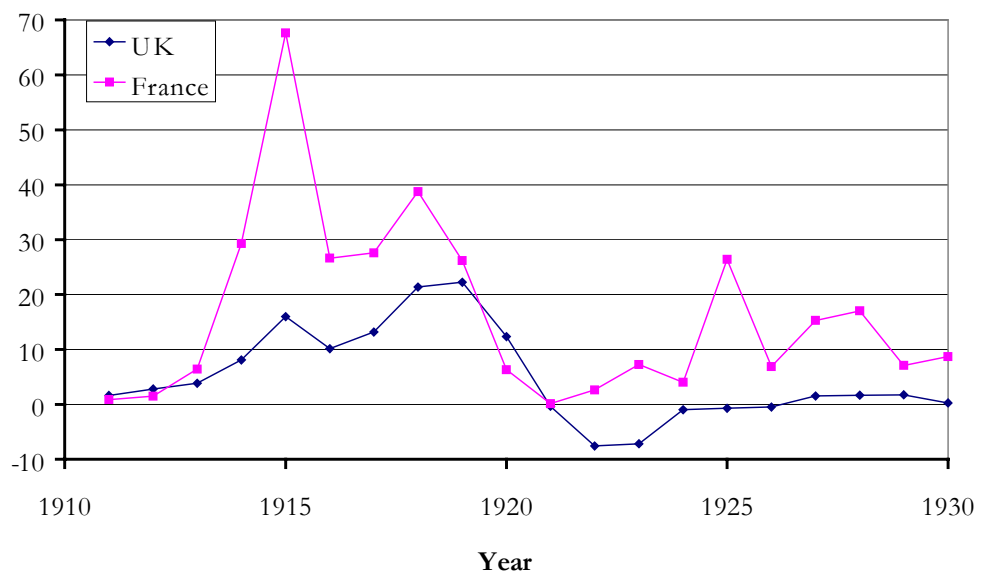

Figure 6: Budget Deficit as a percentage of GDP

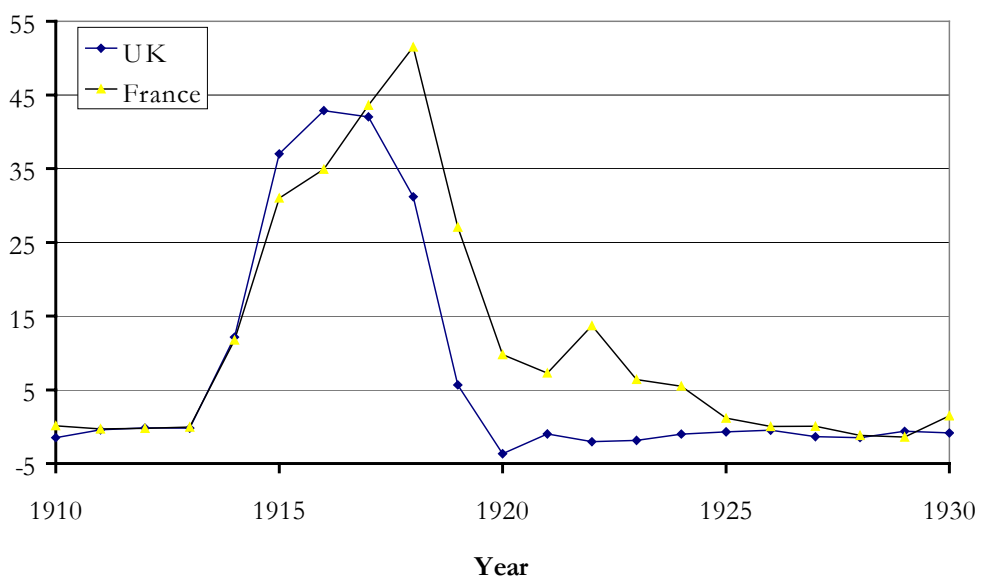



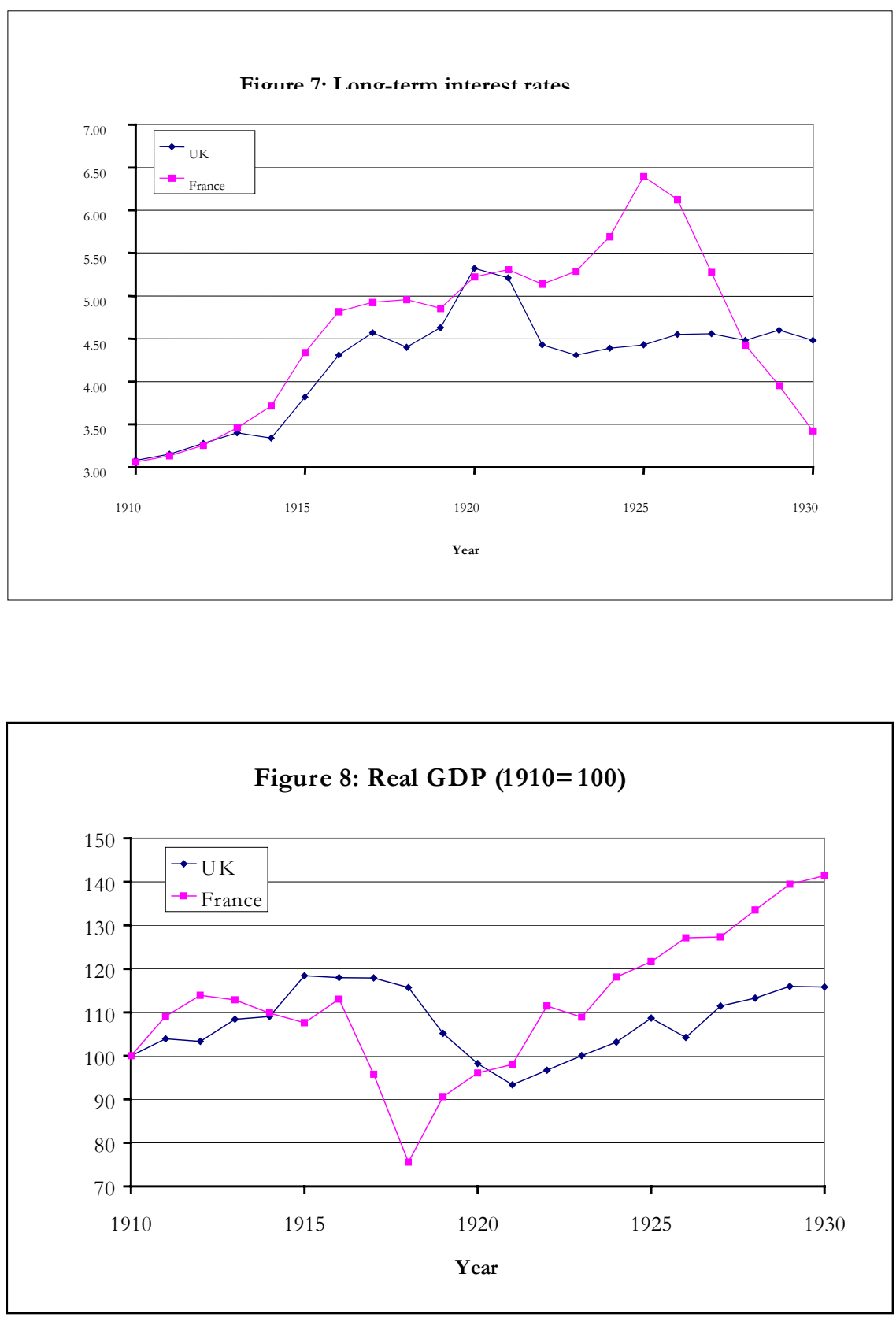

France, like Britain, suffered recession in 1919 - 1921, seen in falling prices (figure 1) and falling industrial production (figure 9) ; but the fiscal deficit declined one year later and by less than in the British case, and debt ratios remained high. Monetary policy was relatively tight up to mid-1923, reflected in the relative stability of the price level (figure 1), high interest rates (figure 3) and a stable exchange rate (figure 2). Fiscal policy tightened progressively : whatever the discussions on the budgetary figures (see appendix), the deficit decreased but didn't disappear before 1926. That delay resulted from discrepancies between the right and the left over how to trim the deficit, but mostly, until 1923, from the hope that German reparations would solve the 
budgetary problem. Only with the German hyperinflation did the French realize that the reparations would not be forthcoming in sufficient magnitude to cover the costs of reconstruction and to reduce the deficit, and that they would be unable to make Germany pay.

Figure 9: Industrial Production index $(1910=100)$

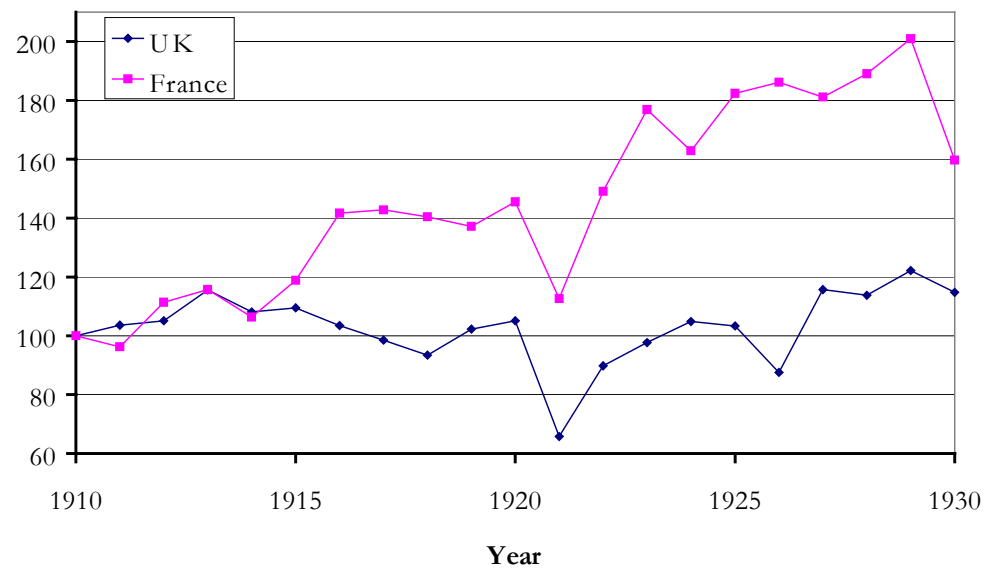

Figure 10: Unemployment rate (\%)

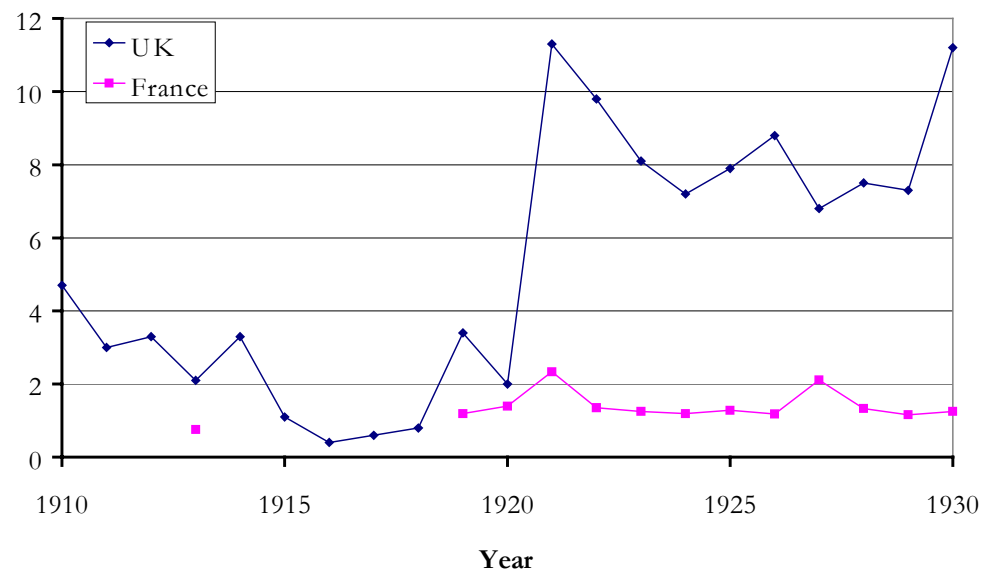


Figure 11: Real wage

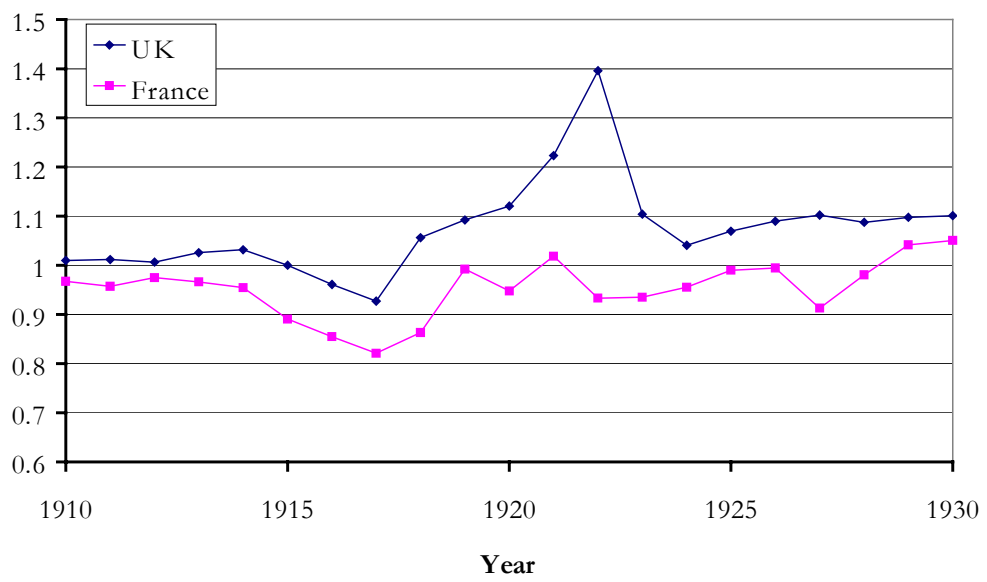

The relative roles of the political impasse and of the recognition of the absence of German payments are difficult to disentangle. On the one hand, the relative stability of prices, long term interest rates and the exchange rate until 1923 suggest that markets believed in the promised stabilization up to a certain point and that the German hyperinflation had an important role in modifying their expectations. On the other hand, the share of taxes in GDP rose from $14 \%$ in 1923 to $17 \%$ in 1926, a jump that compensated for the loss in reparations and allowed the stabilization to take place (A and B bonds from the 1921 settlement imposed a yearly payment of 3 billion gold RM, of which 52\% would go to France. Given the fall in the real price of gold corresponding to the US inflation, this represented no more than $2.5 \%$ of French GDP in the 1920s. Furthermore, the Dawes plan of 1924 only temporarily decreased Germany's obligations, and could even have increased the anticipated payments since the 1921-1923 record had been much below the obligations). More than the political impasse which the conventional story focuses on, the markets anticipated a budget crisis because of the struggle with Germany. This led to capital flight, a deteriorating exchange rate, difficulties in the renewal of short term debt, and finally a monetary expansion by the Bank of France and an acceleration in inflation.

Poincaré's Bloc National temporarily relieved the French crisis by raising indirect taxes. But continued conflict over the distribution of the higher tax burden under the subsequent left-wing Cartel des Gauches government and the threat of a capital levy (Hautcoeur and Sicsic 1999) led to capital flight and a short-term debt funding crisis, further inflation and depreciation of the franc. The Bank of France contributed to the crisis by raising the possibility of a stabilization at a parity different from the prewar one, and by engaging in political attacks against the government (Jeanneney, 1976). The crisis ended with a second Poincaré administration, having the support of 
both left and right ${ }^{2}$. The Poincaré administration ruled out a capital levy, reduced government expenditure, raised taxes, and reduced money growth. These policies restored price stability and encouraged an appreciation of the franc to the point in December 1926 at which it was pegged to the pound at an $80 \%$ depreciated rate. This tour de force resulted from a change of personnel at the Bank of France where the new, Cartel appointed, Governor Emile Moreau helped to convince Poincaré of such a stabilization. Long-term interest rates declined after the 1926 de facto stabilization, likely reflecting a restoration of credibility (figure 7), which was reinforced by the legal restoration of the gold standard in June 1928.

Despite the monetary and financial turbulence, French real performance (output, industrial production and unemployment) was generally superior to that of the British (see figures 8,9 and 10). (Real wages also did not rise as was the case in Britain (figure 11)).

In sum, although, the macro-economic fundamentals in France immediately after World War I were not that far from those in Britain, the French chose not to go the resumption to original parity route. According to Eichengreen (1992), a greater national debt with a larger short-term component, coupled with a weak political economy, explains why the orthodox resumption policy was not followed. Below, we try to confirm that intuition by considering what would have happened to France if indeed the British strategy were tried in 1919, and whether the reasons for the inability to achieve resumption were mostly economic or politic.

One can justify our strategy by the following reasoning: the three speculative attacks ${ }^{3}$ on the exchange rate (in 1919, 1924 and 1926) resulted partly (maybe entirely in 1926) from the absence of a clear commitment similar to that existing in Britain after the Cunliffe report. Such a commitment was likely a necessary condition for imposing the tighter fiscal policy that was needed in 1919 for reconstruction and in 1924 to compensate for the illusory German payments. We then consider whether an early commitment on the British model would have been credible or not.

\section{The model}

From the above discussion, we know that the most important constraints on the stabilization decision were the public finances, encapsulated by the ratio of public debt to GDP. We will consider the economic and political feasability under the counterfactual scenario of an early

\footnotetext{
${ }^{2}$ Poincaré's political clout depended on his previous intransigent attitude toward Germany, which made it possible for him to abandon the expectation of Reparations payments without endangering his political position.
} 
stabilization. But before turning to that scenario, we must more precisely define the stabilization that we have in mind. We then model its impact on the debt/GDP ratio through the main macroeconomic variables affected: the budget, money supply, price level, investment and growth.

Recent as well as past stabilizations (Eichengreen, 1990) usually require at least two conditions to be met: a significant shift in fiscal policy and a change in the monetary regime (in the definition of Sargent (1986). Both changes usually have a direct impact on nominal debt and nominal GDP.

We consider as exogeneously given the change in fiscal policy which was tending toward fiscal balance. Both a reduction in expenditures or an increase in taxes may be considered, although we will think mostly in terms of changes in the tax ratio (especially when considering its impact on the economy). For simplicity, we consider that the government can directly choose the tax/GDP ratio and the ratio of expenditures to GDP.

The change in monetary regime, in the postwar context, had to embody a clear commitment to the gold standard, as Britain had made starting with the Cunliffe report from 1918. Such a commitment implied that the exchange rate be pegged, exchange controls lifted, and price levels and interest rates be taken as exogenous.

We assume that the demand for nominal money is a function of nominal GDP and anticipated inflation ${ }^{4}$. Actually, the M2/GDP ratio, which was growing slowly before the war, rose rapidly during the war from 50 to $70 \%$, reflecting the monetization of the public debt. It then decreased sharply during the inflationary period of 1919-1920, stabilized shortly around 50\%, decreased during the two following inflationary episodes of 1923-26, and rose back to around 50\% thereafter. It seems reasonable to us to consider $50 \%$ as the level of the M2/GDP ratio compatible with the zero anticipated inflation that would occur with a return to the gold standard.

If, at the moment of stabilization the money supply exceeded the real demand for money at the new parity, a clear commitment to monetary contraction would be necessary. This would have had direct implications that must be taken into account not only for the monetary policy conducted by the central bank but also for the government budget. For example, since Bank of France notes represented more than half of M2 in 1919, and the Bank's loans to the State represented $90 \%$ of its assets other than gold, a reduction in the State's debt toward the Bank was necessary for any monetary contraction required by a stabilization (see table 1). We must add any such reimbursement to the budget expenditures.

\footnotetext{
${ }^{3}$ We use the term speculative attacks because in every case the exchange rate overshot its purchasing power parity level; it does not mean that there were not fundamental economic reasons for the attacks (except, maybe, for the third episode, on which see Hautcoeur and Sicsic 1999).

${ }^{4}$ We could not find any statistically significant impact of the interest rate on M2/Y during the prewar period.
} 


\section{TABLE 1: Simple monetary accounting}

Banque de France balance sheet (dec. 1919)

\begin{tabular}{ll}
\multicolumn{1}{c}{ Assets } & Liabilities \\
Gold $\quad(5.9)$ & Capital \\
Credits to the economy $(3,4)$ & Notes $(37,3)$ \\
Loans to the State $(29)$ &
\end{tabular}

Commercial banks balance sheet

$\begin{array}{ll}\text { Assets } & \text { Liabilities } \\ \text { Credits to the economy } & \text { Capital } \\ & \text { Deposits (30) }\end{array}$

Amounts are approximatively what they were at the end of 1919 (see ANNHIST 2003).

In order to reduce M2 (Banque de France' notes + commercial banks' deposits), one may either reduce Notes or Deposits. Notes result from credits or loans created by the Banque de France. Deposits result from commercial bank credits. Thus, one may either reduce loans to the State (three quarters of the Banque de France's assets), or commercial bank credits to the economy.

In 1919 M2 $=67$ billion francs $(37+30)=71 \%$ of GDP. Suppose that a reduction of M2 by 17 billion francs to 50 billion is imposed to reach the M2/GDP $50 \%$ ratio. It would imply :

- either a 17 billion franc reduction in Banque de France' notes, which requires at least a 15 billion franc reduction in the loans to the State (since its credits to the economy are very limited);

- or a 17 billion franc reduction in commercial banks deposits ( $57 \%$ of their amount), which requires a similar reduction in their credits to the economy.

- or a combination of both.

Furthermore, the credibility of the stabilization would also require a significant reduction of these loans: first, because a purely contractionary monetary policy would inordinately reduce the size of the banking system relative to the central bank (see table 1); second, because without an important reduction in the note issue, the gold reserve ratio would prove inadequate.

A last important requirement for postwar stabilization in the French context would be the conversion of short term into long term debt, because of the threat that non-renewal would represent for the public finances. This would have a small impact on the budget through the difference in interest paid on both kinds of debt ${ }^{5}$.

Using this model, we can calculate the impact of the stabilization on nominal debt, which is the first step in our construction of a counterfactual debt/GDP ratio. It depends on the assumptions to be made about the evolution of money demand (and then of GDP), government expenditures and revenues, and the structure of public debt.

The second step is the estimation of the impact of the stabilization on GDP. Our estimation procedure was chosen to give lower bound estimates to our results. Since we will show that a

\footnotetext{
5 This may also have an impact on the liquidity of the banking system since it owns a substantial part of the short term debt. We do not discuss this here because of a lack of available data.
} 
stabilization at the prewar parity was impossible in France, we instead choose a model and some hypothetical scenarios that would maximize the chances of success. In that perspective, we minimize the negative impact of a stabilization on GDP by using a supply side model which does not place much emphasis on the impact of stabilization on demand ${ }^{6}$. This also provides a first (optimistic) attempt at building an anti-keynesian interpretation of the 1920s in France. Another reason for using this approach is that we wish to measure the sustainability of the public debt in the medium run ${ }^{7}$.

One methodological problem we face is that in order to simulate the effects of a stabilization, we need to take the exchange rate and the price level as exogenous, which was clearly not the case during the flexible exchange rate period from 1918 to $1926^{8}$. This change in monetary regime makes it impossible to use existing models of that period like that of Villa (1995), which have a different purpose and which treat the exchange rate and the price level as endogenous ${ }^{9}$. In order to facilitate comparisons, we nevertheless tried to be as close as possible to Villa's model, and we used the same data.

Mainly in order to fix a few ideas, we estimated GDP using three steps. The first one concerns the real wage level.

A classic problem with stabilizations is the resulting appreciation of the real exchange rate because of the persistence of ongoing inflation or (in our case) of the price level. In Great Britain, the overvaluation (in PPP terms) of the pound in the 1920s has been considered to be the central cause of the economic stagnation. A central point in most discussions of the British stabilization is the role of wage rigidities in the transmission mechanism. We estimate the relationship between increases in prices and nominal wage inflation. In our model where prices are exogenous, wages must be influenced by price movements. Since wage rigidities are a short term phenomenon, we add an error correction mechanism to restore real wages back towards their

\footnotetext{
${ }^{6}$ Econometric attempts to introduce demand into our model were not successful either.

${ }^{7}$ Nevertheless, we must remember that although sustainability is based on economic fundamentals, a credibility constraint could also make it impossible for the debt/GDP ratio to rise above too high a level (history suggests 200$250 \%$ ) even for a short period.

${ }^{8}$ There is actually a tradition in French scholarship that considers purely speculative attacks on the exchange rate as the prime mover during the French inflation of the 1920s (from Aftalion 1927 to Jeanneney 1991). Nevertheless, even in speculative attack models, the exchange rate itself results from expectations which make it endogenous in a broader sense (see e.g. Webb 1986).

9 Actually, we must estimate the reactions of the economy during a flexible exchange rate period (the prewar period did not have macroeconomic shocks of the sort the inter-war has) and to simulate a fixed rate regime, which makes almost any model problematic in one of the two regimes. This is because what we want to measure is the change of regime in itself, for which econometrics is of little help.
} 
previous level $^{10}$ (a mechanism provided in real life by unemployment, a variable so badly measured in inter-war France that we could not estimate it).

We then turn to investment. This should serve two different purposes. First investment is the most sensitive economic variable, strongly influenced by expectations of a recession, and deeply influencing aggregate demand. Second, investment contributes to long term growth through the accumulation of capital. In a very classic way, we will consider that it is influenced by factor prices. The government deficit is added because in the absence of monetary finance a deficit may crowd-out private securities issues in the capital market, an effect which is frequently underestimated in an open-economy context by the impact of interest rates.

Finally, we add to this the variation of the tax ratio (taxes/GDP), under two possible rationales. The first, in our supply side perspective, posits a negative effect of taxes on firms ${ }^{11}$. This could affect investment through capital market imperfections creating a role for retained earnings in investment ${ }^{12}$. But, since what we are mostly interested in is the impact of budget deficits on the public debt, we can also consider it in a Keynesian perspective, in which tax increases are equivalent (in their effect on the deficit, under simplifying hypotheses) to cuts in expenditures, which negatively affect demand expectations.

Thus investment is driven by variables which are all exogenous in our stabilization scenario: prices (via nominal wages ${ }^{13}$ ); interest rates (capital controls never succeeded in our period, so that the interest rate was determined as the world interest rate plus expectations of exchange rate changes under the hypothesis of uncovered interest rate parity); and fiscal policy.

From investment, we calculated total capital using a simple accounting procedure (which coefficients were also estimated). We then estimated GDP introducing both the capital stock (in order to introduce supply side accumulation effects) and investment (in order to introduce short term fluctuations). We add past GDP, which allows us to include the impact of a delay required to return the capital stock to full employment after the war. We do not include unemployment or the labor force because of the difficulty of estimating a Philips curve with that period's data.

The model can be summarized in the following way :

\footnotetext{
${ }^{10}$ We should take into account productivity growth, but after the war, it probably converged towards its prewar level, which is implicitly assumed here.

${ }^{11}$ Actually, most increases in taxes during that period affected firms disproportionately, either through direct taxes on profits or indirectly on dividends (Grotard and Hautcoeur 2001).

${ }^{12}$ At least in the medium run, taxation may have an impact on investment only if it redistributes from the productive towards the unproductive sectors of the population (to use terms used by contemporaries) and then increases production costs. As we estimate the impact of taxation using the overall government receipts/GDP ratio, we may overestimate the impact of taxation on business if the tax policy that would have been undertaken together with an early stabilization would have been less biased against firms or revenues from productive activities.

${ }^{13}$ Because wages were actually endogenous, we considered previous period wages for the estimation. However, directly introducing the level of wages would have led us to mix demand with supply effects
} 
$\mathrm{w}=\mathrm{w}\left(\mathrm{p}, \mathrm{Dev}_{-1}\right)$

$\mathrm{Ir}=\mathrm{k}\left(\mathrm{Def}_{\mathrm{N}} \mathrm{Dev}_{-1} ; \mathrm{r}, \mathrm{T}\right)$

$\mathrm{Yr}=\mathrm{y}\left(\mathrm{Yr}_{-1} ; \mathrm{K}, \mathrm{Ir}\right)$

Where w represents nominal wages, Dev is the relative deviation of nominal wages relative to prices since $1913^{14}$ (assumed to represent the error correction term necessary to restore real wages toward their prewar level in the medium run $^{15}$ ), $\mathrm{K}$ the real capital stock, $\mathrm{r}$ the long term real interest rate, Def the government deficit (as a percentage of GDP it is supposed to reflect capital market direct crowding-out of private investment), $\mathrm{T} / \mathrm{Y}$ the ratio of government tax revenue to $\mathrm{Y}$ (nominal GDP), Yr real GDP. When no subscript is added, variables are for the current year.

The estimation results ${ }^{16}$ are presented in table 2 (ordinary least squares; t-stat in parenthesis):

${ }^{14}$ If $\mathrm{w}$ and $\mathrm{p}$ are measured in terms of two indices based on 1913, Devt $=\mathrm{wt} / \mathrm{pt}$.

15 This neglects productivity growth. This is not very important for the initial years, and partly explains the underestimation of GDP in the long term in our simulations. We did not find any solution that would allow us to explicitly introduce productivity growth.

${ }^{16}$ As discussed above, it was not clear whether to estimate the behavior of the economy over the prewar period (one of a fixed exchange rate) or over the inter-war (one including important macroeconomic shocks). Estimation of the nominal wages equation was impossible in the prewar period because productivity variations dominated purely nominal ones during that gold standard anchored economy. We estimated it over the inter-war (results including both inter-war and prewar periods are similar). The equation on capital accumulation and the production function were estimated for the 1896-1939 period. The results did not differ much from one period to another. 


\section{Table 2 : Estimation of the real side model}

Short term wage variations (all variables in growth rates):

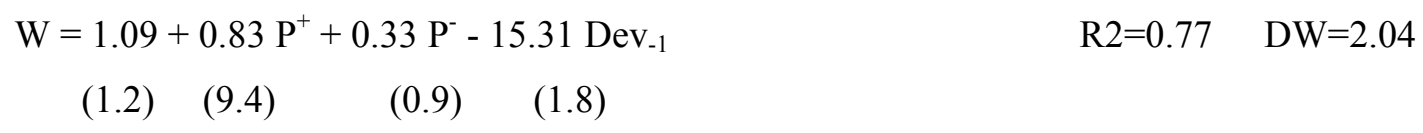

Investment (all variables in growth rates) :

$\mathrm{Ir}=0.038-0.38 \mathrm{Dev}_{-1}-0.0069 \mathrm{r}-1.83 \mathrm{Def} / \mathrm{Y}-1.07(\mathrm{~T} / \mathrm{Y}) \quad \mathrm{R} 2=0.55 \mathrm{DW}=2.1$
(1.8)
$(1.5)$
(3.3)
(2.3)

GDP (in logs) :

$\mathrm{Yr}=1.14+0.6 \mathrm{Yr}_{-1}+0.15 \mathrm{~K}+0.1 \mathrm{Ir}$

$\mathrm{R}^{2}=0.94 \quad \mathrm{DW}=2.2$

(4.5) (6.2)

All variables from Villa (1997), real variables in billions of 1913 francs, wages and prices in indices.

\section{The simulation}

We want to estimate the impact of an early stabilization (on the British model) on the French economy. From the above discussion, we know that the only moment after the war when the return to prewar parity was still possible was 1919 , before the increase in prices that made the gap too large. Was such a stabilization historically possible ? The macroeconomic answer to this question is the reason for this section. Politically, the answer is most likely no : although everyone agreed on the return to prewar parity, no schedule was discussed, and the monetary committee appointed in April 1918 did not have the political clout the Cunliffe committee had (Mouré, $2002: 40$ ).

One could still hypothesize, however, that a joint stabilization could have been a choice for France and Britain if they had wished to manage postwar Europe in a cooperative manner. If they 
had announced early in 1919 that they would rapidly return together to the prewar gold parity and immediately stabilize the franc-pound parity at its prewar level, the signal would have been powerful, and we believe it would have alleviated overvaluation in Britain and inflation pressures in France. Such a solution was never contemplated: the pegging of the franc to the dollar through credits from the allies ceased on March 14th, 1919, starting the depreciation of the franc and French inflation ${ }^{17}$.

What we must consider here however is whether a unilateral French stabilization in 1919 would have been prevented by the size of the public debt.

In order to answer that question, we must simulate the model presented above using the data from the early 1920s. But before doing so, we present our main assumptions concerning the exogenous variables of the model.

First, as a result of the choice of the monetary regime, we assume that the franc would have been fixed at its prewar parity with sterling ${ }^{18}$. With free capital flows between the two countries, interest rates and price levels would then be the same in both countries ${ }^{19}$. We assume that France would have acted as a follower and would have imported British prices and interest rates. With expected inflation eliminated, we assume, as discussed above, that the demand for money would be restored to its prewar level of $50 \%$ of $\mathrm{GDP}^{20}$. With prices given and an estimate of the path of real GDP, we could easily find the level of the money stock and then the necessary adjustment for the money supply, that is the amount of Banque de France's loans to the State which needed to be reimbursed. Needless to say, the relationship between the Banque and the government did not quite work that way. The government had to commit to reimburse the Banque (Mouré, 2002: 47), indeed, the François-Marsal agreements signed in December 1920 between the Banque and the government served just that purpose. They incorporated a promise to retire 2 billion francs a year from the loans.

One may consider that an earlier and more serious stabilization decision would have incorporated a stricter commitment. Furthermore, 2 billion francs were not enough to give

\footnotetext{
${ }^{17}$ This reflected growing American isolationism and Britain's erroneous fear that France could become a dominant power in Europe, when it was actually harmed much more by the war than was Germany, see e.g. Duroselle (1993 : 19).

${ }_{18}$ This assumption has the advantage of being more plausible than a peg with the dollar (which had not yet the same prestige as the pound); alternatively, one may consider that France choose a policy similar to the British one.

19 These assumptions are optimistic because before World War 1 interest rates in France were usually slightly higher than in Britain, and because the level of the debt was higher in France at the end of the war, making a higher risk premium likely. The assumption on prices is also optimistic since with greater amounts of wartime destruction, of foreign debt and of government domestic debt, France would probably require lower prices to maintain the real exchange rate at equilibrium.

${ }^{20}$ In Britain, the money stock in the early 1920s reached higher values relative to GDP than before the war, which may be attributed to expected deflation. Nevertheless, France started with a high monetary overhang, which was not the case in Britain, so that we do not think that France could have benefited from such a high demand for money.
} 
credibility to a stabilization decision taken in 1919. An M2/GDP ratio of 50\% (in line with the prewar level) would then require such a sharp reduction in private bank money as to put the banking system in danger. A simple calculation (such as explained in table 3) shows that commercial bank deposits could decrease by considerable amounts in order for M2 to follow a credible path (which we consider as reaching $50 \%$ of GDP within 4 years, a delay which by itself requires some credibility). This holds even if the reimbursements of the State's loans are given a higher value of 3 billion francs a year, which, we take as a minimum. We thus assume that the government would have repaid 3 billion francs a year by increasing its long term borrowing. Such an amount, if accompanied by a similar reduction in note issue, would also permit the Banque to reach a cover ratio of $35 \%$ within the same time frame ${ }^{21}$, a condition for a successful stabilization.

Table 3: The four year impact on M2 of stabilization under two assumptions on growth.

We assume stabilization of the growth rate of M2 by one half in 1919, thanks to loans to the State and growth of the note issue by half its actual rate (this is consistent with our other assumptions on growth and an early stabilization decision). This gives a 58 billion franc value for M2 in 1919, of which notes represent 33 billion. If the rate of growth of GDP follows its actual path (no impact of stabilization on growth), the $50 \%$ of GDP ratio produces an M2 level of 44 billion francs in 1923, a 14 billion (24\%) reduction from 1919. If French GDP were to grow as it did in Britain, M2 must reach 32 billion francs in 1923. Below we calculate the impact on private bank's deposits if there were no decrease in the note issue and if 3 billion francs in notes were repaid each year consequent upon the government's reimbursement of its loans to the Banque.

\begin{tabular}{lccc} 
& M2 decrease & \multicolumn{2}{c}{ Resulting decrease in private banks deposits } \\
within 4 years & if no decrease in notes & if 3 b./.y notes repaid \\
British growth & $-45 \%$ & $-100 \%$ & $-56 \%$ \\
French growth & $-24 \%$ & $-56 \%$ & $-8 \%$
\end{tabular}

The next and most essential assumption affecting the debt/GDP ratio is the level of taxes. Contrary to Britain, France did not increase taxes during the war. Actually, even the nominal value of taxes decreased at the beginning of the war, and the 5,7 billion francs of taxes in 1918 represented in real value around $40 \%$ less than the 4,3 billions of 1913 . Taxes increased sharply in 1919, with the amount paid almost doubling (when prices increased by only 20\%), but taxes represented only $11 \%$ of GDP (compared to $9 \%$ in 1913 but by contrast $16 \%$ in 1918 and $23 \%$ in

2137 billion less $(7 \times 3)$ gives 16 , of which 6 is slightly more than $35 \%$. 
1919 in Britain). We assume an increase of similar importance in 1920, bringing the tax/GDP ratio to $20 \%$, and another significant increase in 1921, bringing it up to $25 \%$ (this is a higher level than that reached in Britain, and 50\% higher than the highest reached in France during the 1920s).

Finally, we hypothesize about the evolution of public expenditure under a different monetary regime. We will assume that except for interest on the public debt (which path results from our assumption of imported interest rates and an optimistic consolidation scheme ${ }^{22}$ ), other expenditures are maintained in real terms, in the sense that they are adjusted in nominal value for price fluctuations. We consider this choice as a reasonable compromise between the view that inflation decreased real expenditure (which was the case for civil servants salaries) so that deflation would have increased it; and the view which emphasizes the budgetary "laisser aller" resulting from the lack of a nominal monetary anchor.

One may argue that we do not give enough weight to reductions in expenditure as a solution to the deficit. It has often been argued that the compensations for wartime destruction had been subject to opportunism resulting in excessive State expenditure. This cannot be neglected since these compensations were the main reason for the rise in government expenditure (representing around $9 \%$ of GDP in 1920, 12\% in 1921, 8\% in 1922 and 7\% in 1923 before decreasing rapidly (Blancheton, 2000, p.161) ${ }^{23}$. Nevertheless, the existence of devastated regions for which national solidarity was required was a French (and not a British) problem so that imitating the British reduction in expenditure was much more difficult in France.

One should also notice that a substantial share of the compensations does not appear in government expenditure since it was financed through loans from the newly created Crédit National (which issued 15 billion francs of bonds between 1919 and 1922, more than $10 \%$ of 1920 GDP). So we choose to maintain the real value of these expenditures in our stabilization scenario, and put the rest of the adjustment effort onto tax increases.

\footnotetext{
${ }^{22}$ A last, mostly technical assumption concerns the structure of the public debt. It affects slightly the debt/GDP ratio via the budget deficit, but only up to the (small) difference between the interest rates on short term and long term debt. We assume that the short term debt is consolidated under the following scheme: instead of its actual evolution, it remains in 1919 at the 1918 peak value of 56 billion francs (instead of its actual level of 20 billion higher) and decreases thereafter by 10 billion a year up to 6 billion francs in 1924 and 0 afterwards. This is a relatively slow pace in comparison with the sharp reduction in the short-term debt that actually occurred after 1926.

23 One should add that war pensions were also generously distributed, not only to soldiers but to their families. This represented yearly around $2 \%$ of GDP during the 1920 s.
} 


\section{Results}

Using the equations estimated in the previous section and our assumptions discussed above about the evolution of the exogenous variables, we can simulate our counterfactual. One must remember that our assumptions are quite optimistic for the result of the stabilization ${ }^{24}$.

One might have deduced from figure 4 that the debt level was not much more of a problem in France than in Britain (the debt/GDP ratio was 1.8 compared to 1.4 in 1919). In fact, that difference would have been greatly expanded by the consolidation process under the "British" scenario that we assume, because 1/ the "money overhang" was much more important (without already being entirely reflected in prices), and since much of the money creation corresponded to loans to the State, they had to be repaid if the stock of money had to decrease; 2/ public expenditures were so high that even sharp increases of taxes on the British model would not eliminate the deficit.

We show in figure 12 the likely paths of nominal debt under our assumptions and various hypotheses on the evolution of real GDP. Under the pessimistic one, France follows the British growth rate from 1919 on (this corresponds to the Keynesian thesis that considers the recession as the result of the stabilization). Under the optimistic one (in favor of which we give some arguments below), the French growth rate is not affected by the stabilization. We consider the case where the government is not able to raise the tax level as mentioned in our scenario in order to give an idea of the importance of this assumption ${ }^{25}$. If one considers the most optimistic "Taxes and French growth" scenario, one may summarize the impact of our various assumptions in the following manner. The stabilization does not much affect the primary budget, except for the rise

\footnotetext{
${ }^{24}$ This is the case for the structure of the model and of the assumptions about the exogenous variables. One might suppose that we have neglected the impact of our hypothetical scenario on the French government's financial position $v i s-\grave{a}$-vis foreign countries, that is the value in our scenario's francs of German Reparations and interest payments on war debts to Britain and the US. In fact, by considering government revenues and expenditures in real terms, we considered most of their impact. To see this suppose that German Reparations were to follow the actual pattern in terms of gold marks. Converted into francs, they would bring a smaller amount of revenues to the French Treasury in our scenario, the difference being measured by the ratio of our hypothetical exchange rate to the actual one. This ratio does not differ much from the ratio of our hypothetical price level to the actual one, so that the impact of basing our calculation on the exchange rate would not add much to the result. The same is at least as true for interest payments on inter-allied debt, since their real value may better (in an ability to pay reasoning) be defined in terms of real francs (actual nominal payments divided by price level) as in terms of foreign currencies. One may also consider that we underestimated the role of foreign relations. We have been unable to find empirical evidence of a substantial role of foreign trade on output. This is contrary to the conventional wisdom, which says that the exchange rate depreciation and the real undervaluation of the franc during the inflation period had an important role in stimulating demand and promoting economic recovery. Furthermore, our scenario with a less undervalued franc is compatible with a higher trade deficit, which is necessary in order for foreign saving to finance part of the government debt consolidation process without endangering too much private investment. Finally, we neglect the various effects of a French stabilization on British growth and interest rates. The outcome might have been favourable, if considered as more cooperative. But this is highly speculative.

${ }^{25}$ We do not give it in the "British growth scenario", but in that case debt would clearly be even much higher.
} 
in taxes, which is an essential feature, representing 61 billion francs more in public earnings from 1919 to 1925 than was actually the case. The debt consolidation process significantly affects the amount of interest paid on the public debt ( 9 billion francs less than the actual payments). The monetary consolidation (less recourse to monetary financing and reimbursement of 3 billion francs a year to the Banque de France) imposes the issuance of 26 billion francs more of public debt. One may conclude that even raising taxes enormously and benefiting both from a high growth rate and from low interest rates, the level of public expenditures and the necessary abandonment of monetary financing of the deficit made it impossible to significantly reduce the level of nominal debt.

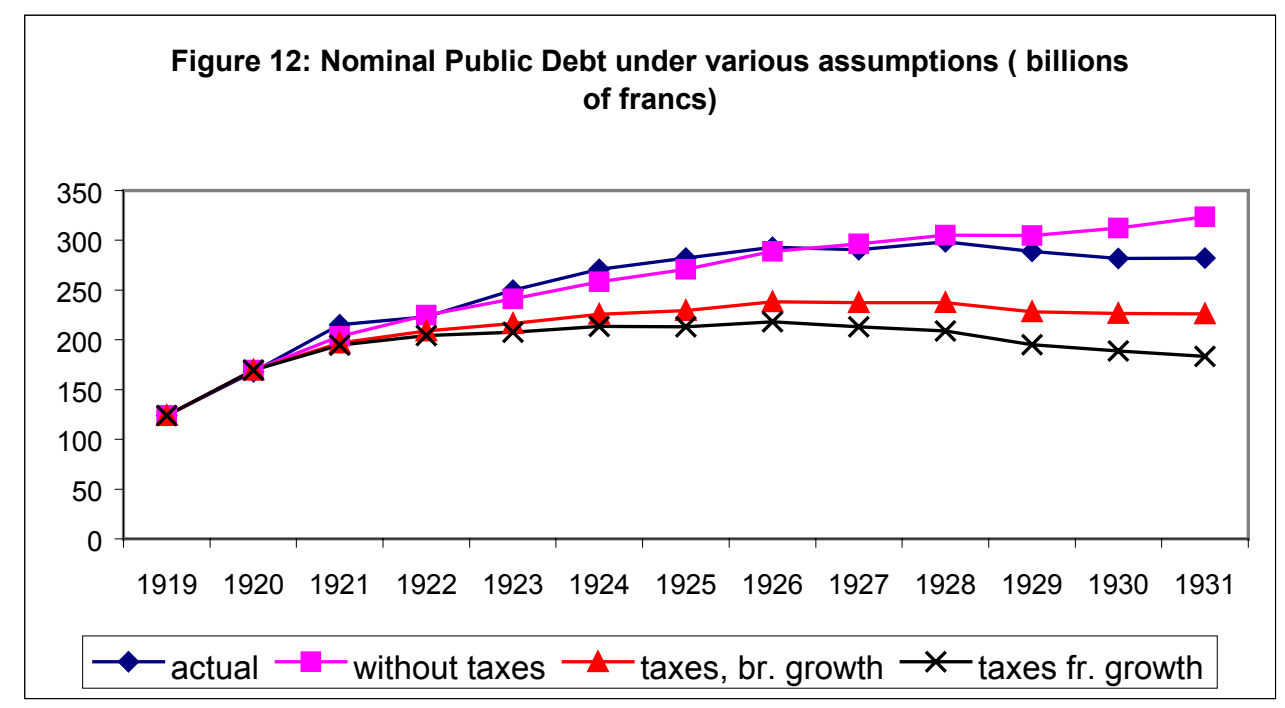


Table 4: summary of the main impacts on public debt in the hypothesis of high growth

This table shows the impact of the various assumptions in our scenario on public debt, cumulated from 1919 to 1925 (in billions francs).

\begin{tabular}{lllc} 
& Our scenario & $\begin{array}{l}\text { Actual } \\
\text { amounts }\end{array}$ & $\begin{array}{l}\text { Relative increase (+) or } \\
\text { decrease (-) of debt in } \\
\text { the scenario (A - B) }\end{array}$ \\
$\begin{array}{llll}\text { Primary deficit } \\
\text { (except for new taxes) }\end{array}$ & 61,6 & 64 & $-3,4$ \\
New taxes & -61 & 0 & -61 \\
Interest on short term debt & 12 & 28 & -16 \\
Interest on long term debt & 56 & 49 & +7 \\
Monetary consolidation & 26 & 0 & +26 \\
\hline Total debt increase & 94,6 & 141 & $-46,4$
\end{tabular}

If we turn now to the real side of the simulation (that of real GDP), we will observe that it will not play much of a role in our results. Because of the level of the nominal debt in our scenario, any reasonable assumption about the path of real GDP will imply an excessively high debt/GDP ratio.

The simulation of the wage level using equation 1 suggests a dramatic increase in real wages when prices decrease, followed by a slower decrease than in the British case (figure 13). This may reflect an overestimate of French nominal wage rigidity. Nevertheless, high rigidity of wages also appeared in the 1930s. Some observers explain this by the importance of independent labor in France compared to the case in Britain (which makes unemployment less of a threat to workers, with the resulting smaller impact on wages, and also a smaller impact through demand on GDP). 


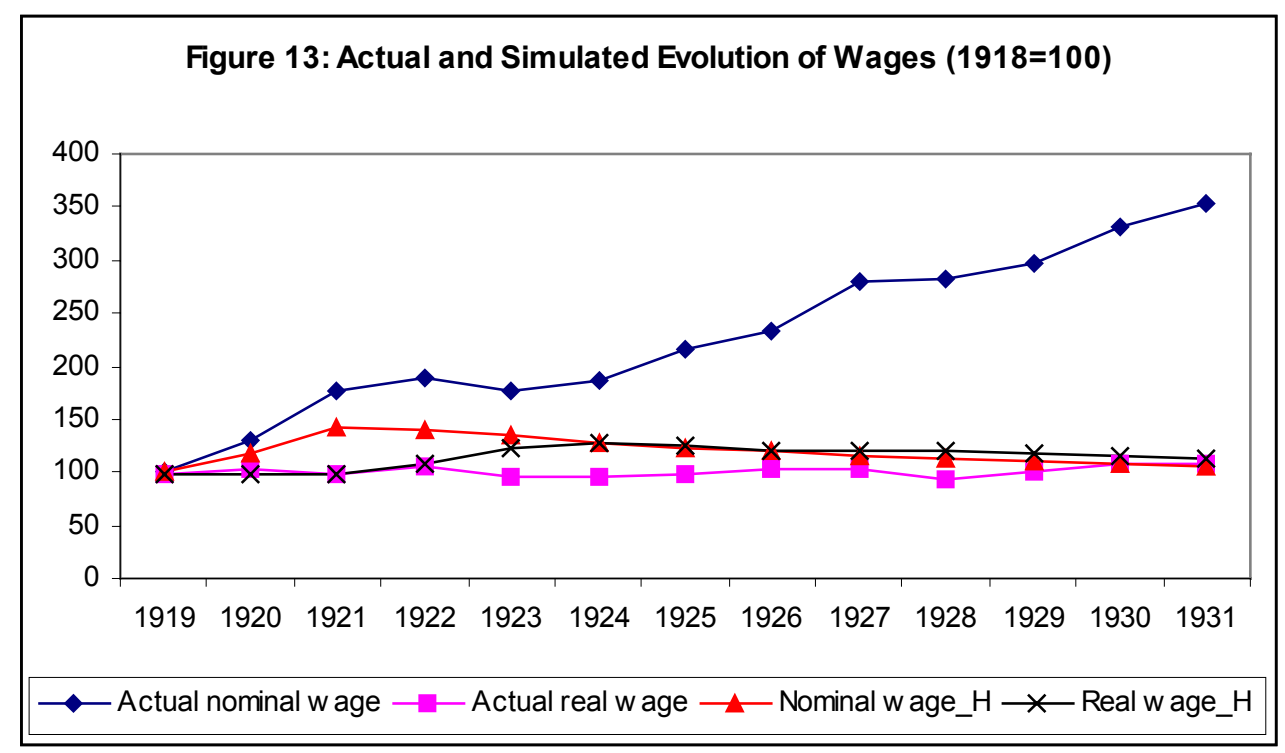

The heart of our simulation is the rate of growth of investment, from which we calculate the capital stock and GDP. Some simulations (figure 14) show that investment is very sensitive to the assumptions made about tax increases (mostly), the wage level or interest rates. H1 is our basic scenario; $\mathrm{H} 2$ to $\mathrm{H} 5$ are given in order to suggest the relative importance of the various effects we separated; H2 presents our scenario except for the impact of interest rates, considered as zero ; H3 doubles the impact of all variables; $\mathrm{H} 4$ shows our scenario except for the impact of real wages ; H5 gives it except for the impact of taxes ${ }^{26}$. A comparison between our simulations of GDP, its actual path and the value it would have had under British-style growth (figure 15) shows, as our choice of model implied, that our model certainly underestimates the short term negative impact of an early stabilization on GDP (thus making it easier), and underestimates the long term growth of GDP (because it neglects productivity growth). It may also provide some argument in favor of a new classical interpretation of interwar history. At least, it suggests that the most important constraint on stabilization was perhaps less the reaction of the real economy than that of the financial sphere.

\footnotetext{
${ }^{26}$ There was actually much discussion among contemporaries on the impact of taxation on the economy, and the solution proposed was to concentrate it on the very beneficiaries of the deflation - - those rentiers with nominal fixed incomes. This was difficult not only because of their political clout - - taxing only public debt was too similar to a default, and taxing all assets was politically difficult and economically controversial.
} 

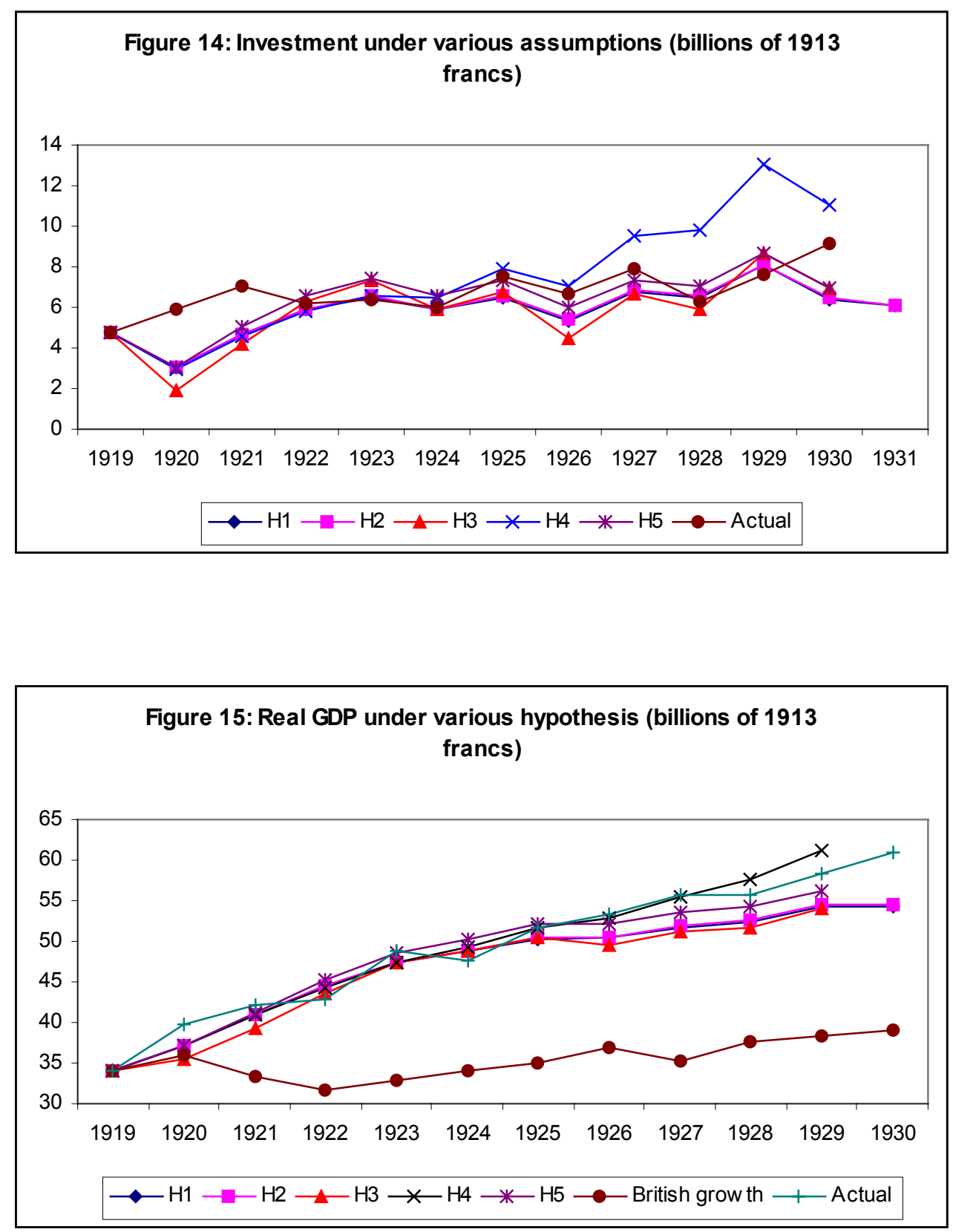

This is confirmed by a look at the debt/GDP ratios in figure 16. We took as references the polar cases of French and British actual growth rates, since the most optimistic scenarios we simulated above for GDP were quite similar to the actual French path. We observe that in both cases the debt/GDP ratio rises above sustainable levels (it reaches $240 \%$ even in the most optimistic one), because even very high levels of taxation (such as in our main scenario) cannot entirely eliminate the budget deficits. This confirms that making the financial constraint less 
binding depends more on financial or monetary reforms (including inflation) than on the economic situation. More importantly, no scenario is able to lower the debt/GDP ratio below 2, even after a decade of very tight budgetary policy. This suggests that following Britain was probably impossible in post-war France, even on the assumption that the French would have accepted a major increase in taxes and under optimistic assumptions about the reaction of the economy. This

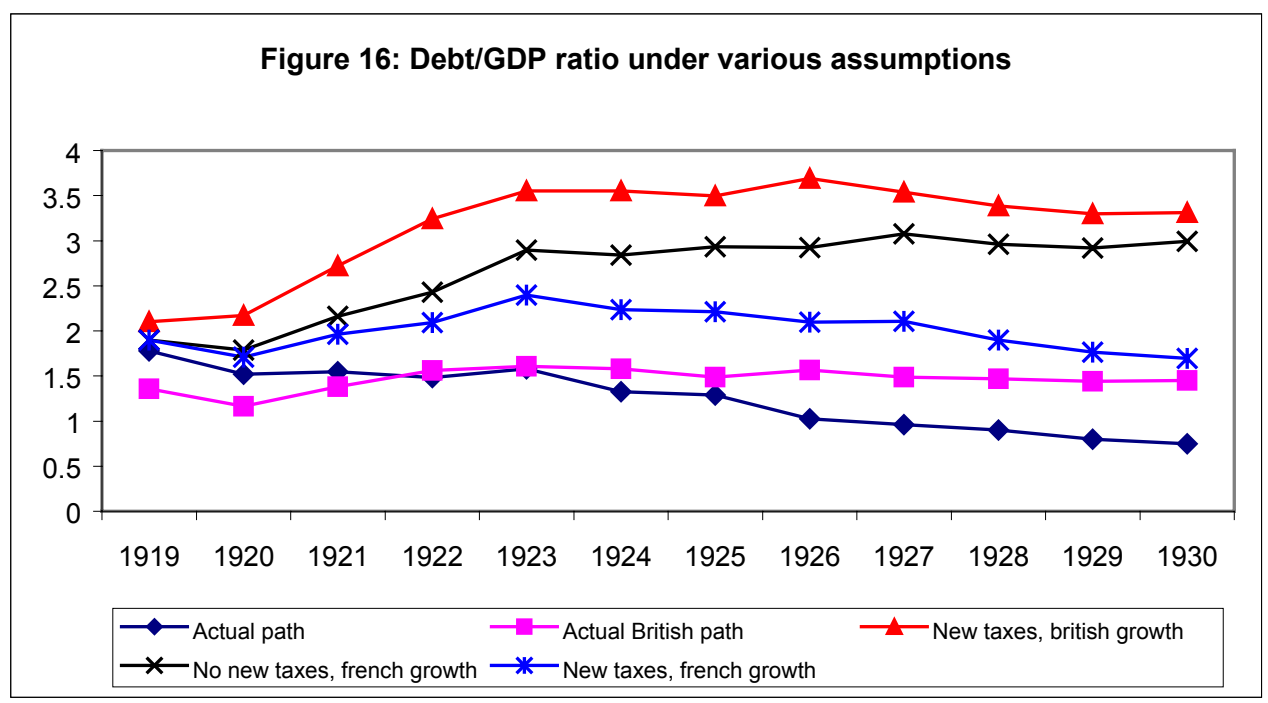

outcome results mainly from the level of the public debt, the monetary overhang at the end of the war and the size of necessary public expenditures.

\section{$\underline{\text { 5. A stabilization in } 1924}$}

The previous paragraphs show that no stabilization was possible in 1919. During the following years, the debt/GDP ratio decreased mainly during two short periods in 1920 and 1924-26. Stabilization occured after the second one. One might wonder whether it could have been realized earlier. In 1920-23, the political preference for a return to prewar parity made any attempt at stabilization unlikely to succeed. Nevertheless, market interest rates show that a stabilization including a limited devaluation was expected throughout 1920-1924 (Hautcoeur and Sicsic 1999). This solution became more likely in early 1924. The reasons for this include the facts that: the German hyperinflation had just made clear that Germany would not pay and inflation was a serious danger; the French Parliament accepted the plan to sharply raise most taxes (the "double decime", a 20\% increase in all taxes), bringing the budget almost to balance; this helped Poincaré, 
who was still the head of the government, to successfully stop a currency crisis (the pound rose up to 123 francs on March 8 and returned to 63 on April 23); opinions changed in favour of a stabilization recognizing a substantial devaluation of the franc (especially at the Treasury under P. de Mouÿ) (Blancheton 2000; Mouré 2002: 64ss) ; and the preparation of the Dawes Plan which created a favorable international environment even if it did not solve the problem of French debts to the Allies.

Consequently, we construct a stabilization scenario for April 1924, a scenario that Poincaré could have pursued would he have won the elections, and even if it had been done before the elections and he had lost, it is doubtful that the successor Cartel des Gauches would have abrogated $i^{27}$. Its main building blocks would be the following: stabilization at a level consistent with purchasing power parity, after which France would follow the path of British prices and interest rates.

A significant question is the level of the exchange rate to produce such a stabilization. We propose an exchange rate of 55 francs per pound sterling as the stabilization rate, since it is the one that Sauvy considered best corresponded to purchasing power parity ${ }^{28}$. It is considerably below the mean rate of 75 for 1924 but near the April rate of 63, making a successful stabilization more difficult to achieve. Actually, a higher rate in terms of francs per pound would mean more depreciation of the franc, facilitating exports, lowering the interest rate compatible with interest rate parity, and so probably raising real GDP. It would also eventually allow more room for price increases, thus raising nominal GDP. Both effects would decrease the debt/GDP ratio. Since we will demonstrate that a stabilization was possible in 1924, this hypothetical exchange rate makes proving our point more difficult and any other plausible rate would make stabilization easier to achieve.

For this exercise, we cannot use our previous model to simulate GDP since it was constructed in order to bias the result in favor of a successful stabilization. We propose instead to consider two paths for GDP. First, the pessimistic case, where the growth rate is assumed to be that of the UK after its own 1919 stabilization decision. Second, the optimistic case, in which the actual French growth rate is not modified. We believe that the "British" path would have been unlikely for France since poor British economic performance in the early 1920s reflected: in part the transition from the war economy to peacetime which was no longer the case in France in 1924; in part the international context (in 1921); and in part the deflationary policy followed by the British

\footnotetext{
${ }^{27}$ Based on the observation that left wing parties are often strong supporters of financial orthodoxy, e.g. both the British and French experiences in the 1930's, and the French left proclamations in the 1920's.
} 
(which is not considered to be the case in France since we only assume a stabilization of prices). We take this scenario as the "worst case".

In both cases, we assume that interest rates follow the British path, exactly as in the 1919 scenario. New taxes would have been created so as to raise the tax/GDP ratio to $20 \%$ in 1924 and $25 \%$ in the following years. This represents an important rise, although not such a jump as in the 1919 stabilization scenarios, and it reinforces the idea that the real impact of the stabilization should be small. The short term debt is consolidated at the same rate as in the 1919 scenario (by 10 billion francs a year beginning in 1924).

On the monetary front, the difference between this stabilization scenario and the 1919 situation is that, thanks to the flight from the currency in the years 1922-23, a stabilization leading to a M2/GDP ratio of 50\% would require an increase of the money supply (figure 17). And since note issues represented only half of M2 at the end of 1923, a decrease of Banque de France loans to the government was not required. Such a stabilization law, we posit would have revalued the gold reserves (approximately from 5.5 to 11 billion francs), and the nominal profits gained would have been used to cancel part of the government debt, as it was the case in 1928. So the debt would be no more than 18 billion francs, half of the note issue. The gold reserve would then represent almost one third of the note issue of 37 billion francs. The decrease in the loans to the government would then have a purely psychological significance. One billion a year would be sufficient, and its negative impact on the budget would be compensated by its positive impact on monetary policy. Since M2 would not have had to decline, and the note issue would decrease, the Banque could relax slightly or at least not harden its monetary policy. This also suggests that our results are biased against a positive outcome from the stabilization.

\footnotetext{
${ }^{28}$ That is Sauvy's estimate of the PPP exchange rate at that moment. There has been considerable debate over the correct price indices to use to calculate PPP for that period, and discussions about purchasing power parity calculations in a context of important structural changes (since the prewar period). See Mouré (1996) and Sicsic (1992).
} 


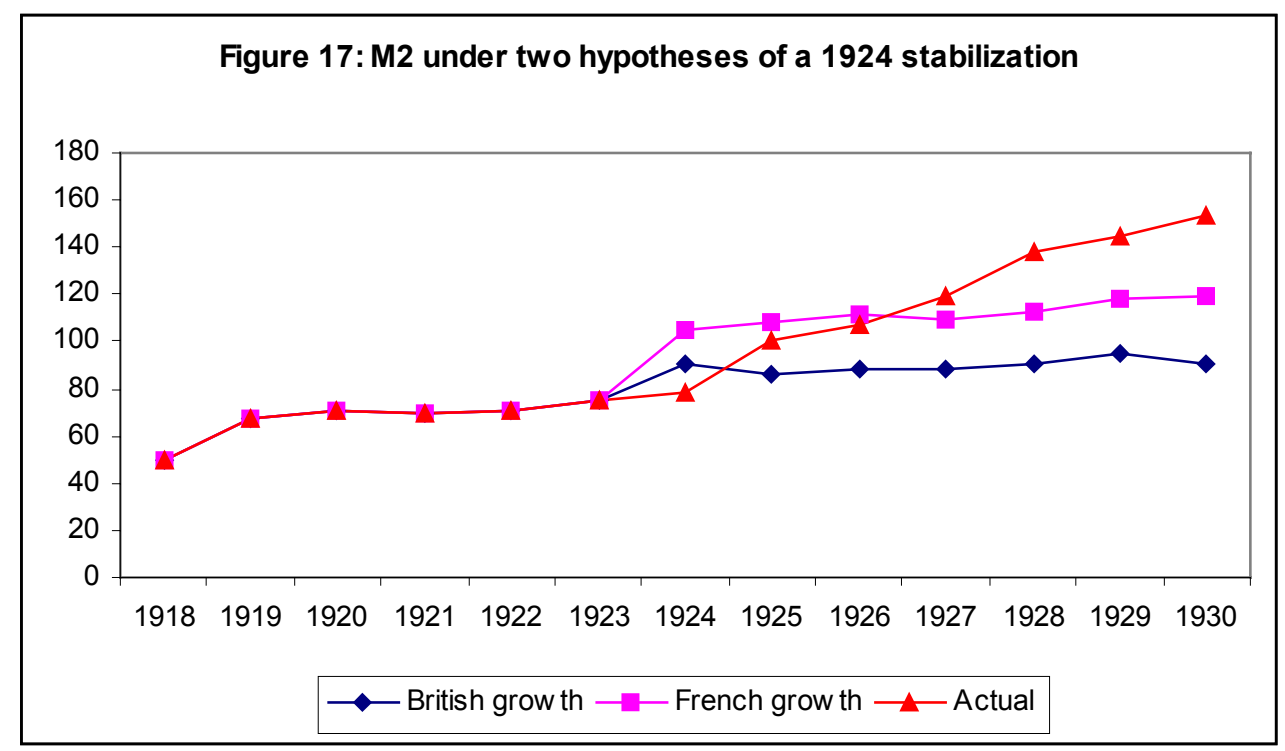

We calculate the path of the debt/GDP and deficit/GDP ratios in a combination of these hypotheses in figures 18 and $\underline{19}$. The debt/GDP ratio never rises above 2, even under the pessimistic growth scenario and even if no new taxes are collected. Moreover, since a better international environment in 1924 made it more likely for growth to be present than was the case in Britain in 1919, we must conclude that a stabilization was possible in 1924 in France, even at an ambitious exchange rate such as one half the prewar parity.

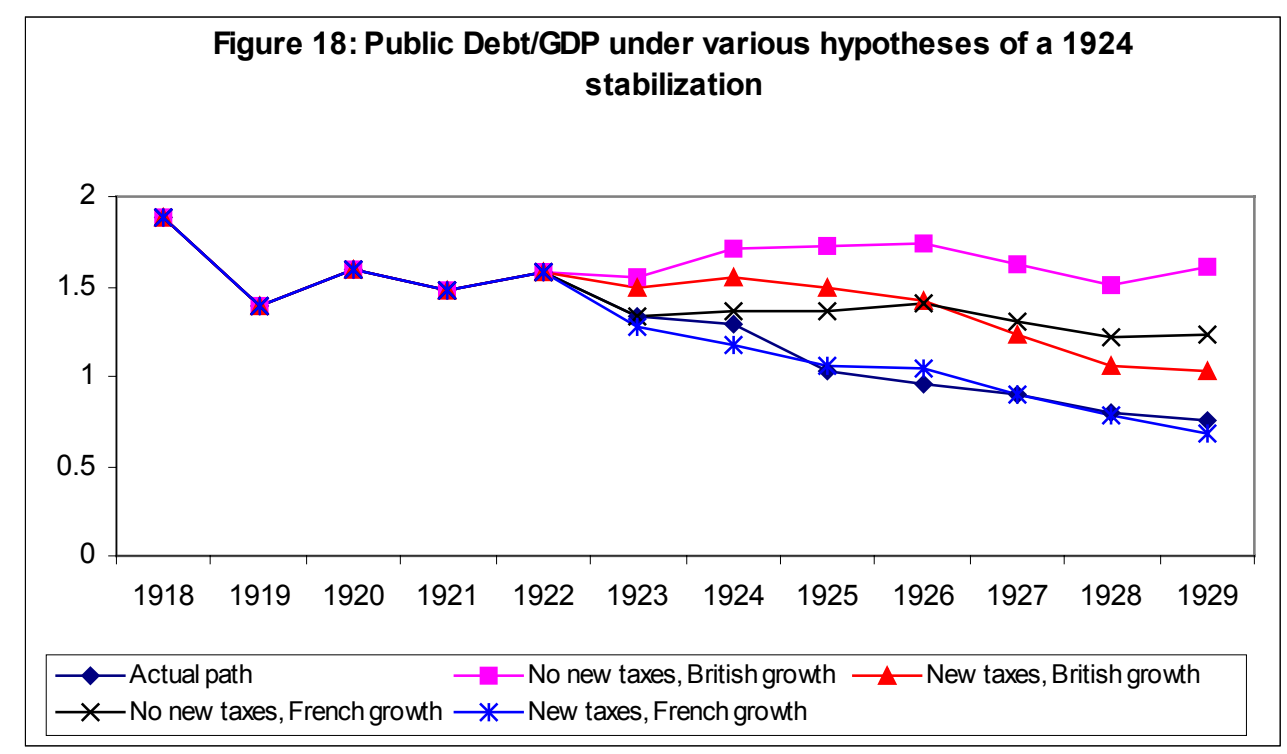




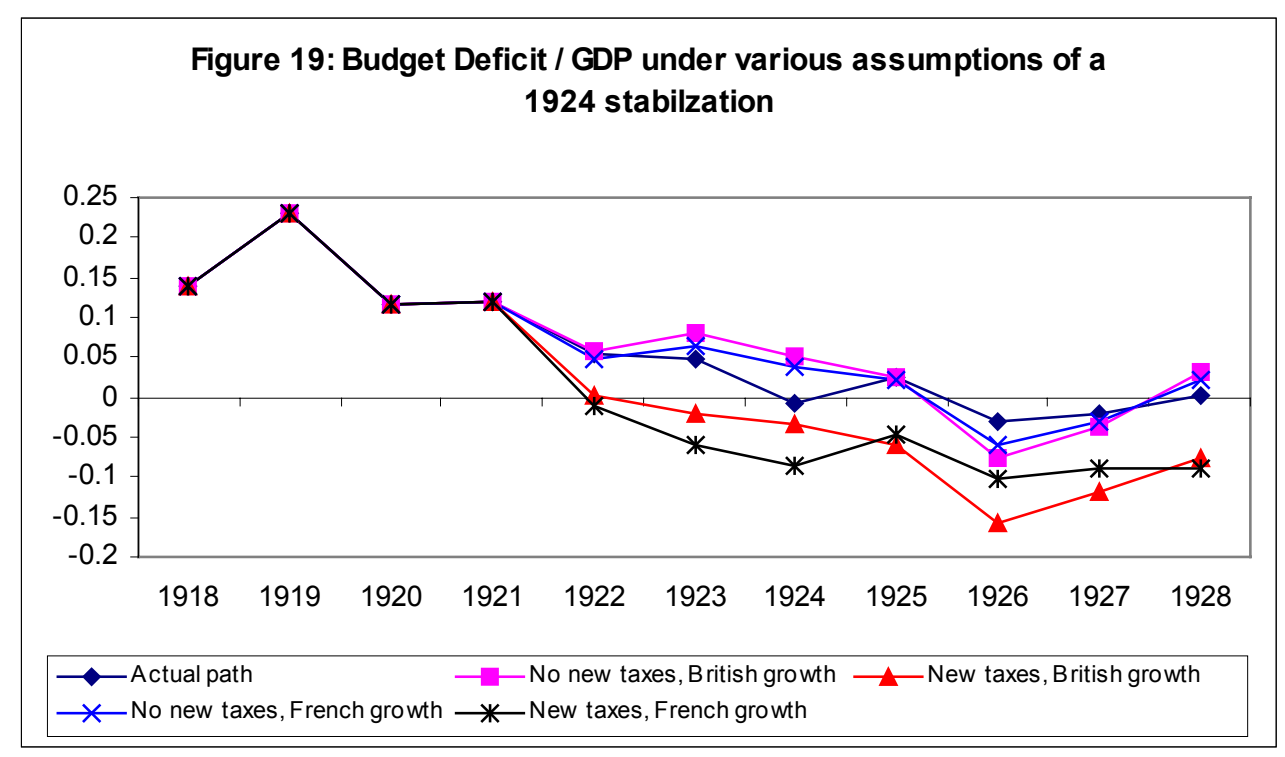

\section{Conclusions}

We have estimated the impact of an early stabilization on the British model for the French economy under very optimistic assumptions: that France would immediately benefit from the low British level of long term interest rates and from price stabilization; that the budget deficit would be reduced with little or no cost; and that the impact of the stabilization on GDP would be very limited.

Our main conclusion is that such a stabilization was impossible because of the salient problem of the French economy after the war - - the excessive level of the public debt and the monetary overhang. Under any plausible assumptions, an early stabilization would have pushed the debt/GDP ratio well above 2 during many years, most likely an unsustainable level. The high debt ratio we argue makes our stabilization scenario quite unlikely because it would have damaged the government's credibility even were the serious distributive conflicts resolved. The apparent solution of a capital levy, which would have reduced the volume of the public debt, was not possible - - not only because of the general difficulties such a solution would have faced (described by Eichengreen, 1990), but also because the increase in the real value of private debt would likely have driven many businesses, and then many banks, to failure.

This suggests that not only political considerations but also economic (more precisely financial) constraints made an early stabilization on the British pattern impossible to realize in France, probably despite the willingness of many politicians and the Banque de France. 
Later on, a stabilization was politically difficult not only because it was only a pis-aller for believers of the franc Germinal but because there was no obvious (and then credible) level where the stabilization could be easily fixed. Nevertheless, we have shown, using both a detailed look at the chronology and counterfactual calculations similar to the preceeding ones, that the most virulent inflationary period, that of 1924-26, could have been avoided with a stabilization in 1924 at a devalued parity of 55-75 francs per pound, a much higher rate than the 125 francs parity that would be fixed in 1928. Such a stabilization had became possible because the budget had been (almost) balanced and the debt had been deflated by inflation and growth. The French had also reduced their demands for German Reparations, which contributed to an easier international settlement.

One would be wrong to consider that the difference between our counterfactual 1924 stabilization and the actual de facto stabilization of 1926 is not that great. However, a 1924 stabilization would have had some important political advantages in the long term. France would have stabilized more or less in line with Britain and Germany. This would have reinforced her credibility and world position. Consequently, the Banque de France would not have had its vanity wounded by the dominant position of the Bank of England. It would have assisted in other European stabilizations, putting less pressure on Britain and building a more balanced and cooperative political system in Europe. The real exchange rate of the franc would have been more in line with that of the pound, limiting gold flows to France, the "international misallocation of gold", and the pressure on the international monetary system in the late $1920 \mathrm{~s}$.

The obstacles to such a beneficial stabilization were mostly political: within France, it implied one last tax increase which provoked sharp debates; it also required a less conservative Banque de France. But also, the obstacles were many outside France including: US isolationism and opposition to any new loan to France (in contrast with Germany); erroneous British fear of French domination in Europe; and British reluctance to share their monetary prestige. These obstacles contributed to make it impossible to achieve such a Pareto-improving cooperative solution. Perhaps had the IMF been in existence in the 1920s to provide the necessary funding, the outcome would have been very different, and the gold standard would be less remembered as a system so prone to produce great depressions. 


\section{$\underline{\text { References }}$}

Aftalion, A. (1927). Monnaie, prix et change. Paris.

ANNHIST (2003) : a database for Banque de France statistics : http://www.banque-

france.fr/fr/stat/main.htm

Bayoumi, T. and Bordo, M. D. (1998). 'Getting Pegged: Comparing the 1879 and 1925 Gold

Resumptions." Oxford Economic Papers, Vol. 50 (January), pp. 122-149.

Benjamin, D. and Kochin, L. (1979). 'Searching for an Explanation of Unemployment in Interwar Britain', Journal of Political Economy, 87, 441-78.

Benjamin, D. and Kochin, L. (1982). 'Unemployment and Unemployment Benefits in $20^{\text {th }}$

Century Britain: a Reply to our Critics', Journal of Political Economy, 90, 410-36.

Blancheton, B., Le Pape et l'Empereur, Albin Michel, 2000

Bordo, M.D. and F.E. Kydland (1995). "The Gold Standard as a Rule: An Essay in Exploration." Explorations in Economic History.

Bordo, M.D., B. Eichengreen, D. Klingebiel, and M. S. Martinez-Peria (2001), "Is the Crisis

Problem Growing More Severe?” Economic Policy 32 (April), pp. 53-82.

Bouvier J. (1984) "The french banks, inflation and the economic crisis, 1919-1939", The Journal of European Economic History, XIII (2), pp. 29-80.

Broadberry, S. (1986) The British economy between the wars, Blackwell.

Broadberry, S. and A. Ritschl (1995), "Real wages, productivity and unemployment in Britain and Germany during the 1920s", Explorations in Economic History

Debeir, J.-C. (1980) "Inflation et stabilisation en France, 1919-1928", Revue Economique, XXXI, pp. 622-647.

Eichengreen, B. (1992). Golden Fetters: The Gold Standard and the Great Depression, Oxford University Press, New York. 
Eichengreen, B. (1990), “The capital levy in theory and practice”, in R. Dornbusch \& M. Draghi, Public debt management: theory and history, Cambridge: CUP.

Grotard, S. and P.-C. Hautcoeur (2001) "Taxation of corporate profits, inflation and income distribution in France, 1914-1926", mimeo.

Hautcoeur, P-C. and P. Sicsic (1999) "Threat of a capital levy, expected devaluation and interest rates in France during the interwar period" European Review of Economic History, III, pp.25-56. James, H. (2001), The End of Globalization, Lessons from the Great Depression, Cambridge (Mass.) : Harvard University Press.

Jeanneney, J-M, (1991) "Monnaie et mécanismes monétaires", in M. Lévy-Leboyer \& J.-Cl. Casanova (eds), Entre l'Etat et le marché, Paris: Gallimard, pp. 289-329

Keynes, J.M. (1929 \& 1972). 'The Economic Consequences of Mr. Churchill', in The Collected Writings of John Maynard Keynes, Vol. IX. Essays in Persuasion, London : MacMillan.

Maizels, A. (1970) Growth and Trade, Cambridge : Cambridge University Press Marseille J. (1980), “Les origines "inopportunes" de la crise de 1929 en France”, Revue économique, XXXI (4), pp.648-684.

Mitchell, B.R. (1992) European Historical Statistics, New York : MacMillian.

Mouré, K. (1996), "Undervaluing the franc Poincaré", Economic History Review, XLIX, 1, pp $137-53$

Mouré, K., (2002) The Gold Standard Illusion, France, the Bank of France, and the International Gold Standard, 1914-1939, Oxford : Oxford University Press.

Pollard, S. (ed.) (1970). The Gold Standard and Employment Policies Between the Wars, Methuen, London. 
Th. Sargent (ed.) Rational expectations and inflation, N.Y.: Harper \& Row, 1986.

Sauvy A., (1984) Histoire économique de la France entre les deux guerres, Paris: Economica.

Sicsic P., "Was the Franc Poincaré Deliberately Undervalued ?", Explorations in Economic

History, 29, 1992, pp. 69-92.

Temin, P. (1989) Lessons from the Great Depression, Cambridge (Mass.) : MIT Press.

Thomas, T.J. (1981). 'Aggregate Demand in the United Kingdom 1918-45', in R. Floud and D.N. McCloskey (eds), The Economic History of Britain Since 1700, 2, Cambridge University Press, Cambridge.

Villa P. (1995), Séries macro-économiques historiques (INSEE Méthodes, N62-63, Paris, 1997), (or http://www.cepii.fr/francgraph/bdd/villa/mode.htm).

Webb, St. (1986), « Fiscal news and inflationary expectations in Germany after World War 1 » Journal of Economic History, 46 (3), pp. 769-94. 


\section{APPENDIX: some details on the calculations and data}

Data for all the graphs in section 2 come from the database used in Bordo et al (2001) and Mitchell (1992). Data for the estimations and simulations are from Villa (1997). The most debated data for the period are the budget deficit and the public debt. Available series for the debt include Sauvy (1984, vol.3, p. 16), Villa (1997) and Bonnefous (reproduced in Mouré, 2002, p.42). Differences are important (see graph. A1). We used Villa's series as being the most favourable to a stabilization in 1919 and the least one for a late stabilization. Budget deficit series include that of Villa (1997), and two series reproduced in Mouré (2002, p.42), from Bonnefous and from a Ministry of Finance archival document (B33985).

The crucial element in the paper is the calculation of the amount of public debt. It is calculated using Villa's (1997) series DETTE (thereafter D), DGLT, DGCT (for total, long term and short term debts), AVANCES (for Banque de France's loans to the government (thereafter AV); and BFG (budget deficit).

We have: DETTE $=$ DGLT + DGCT

In theory we should have BFGt $=$ Dt - Dt-1 since debt is measured in nominal terms. In fact, some variations in the series of the debt level exceed the budget deficit of the corresponding year. This results from different sources for the two series. We decided to give a priority to the debt series, which can only minimize the debt level, going against our main point. So we added to the deficit the debt variations exceeding $\mathrm{it}^{29}$.

In order to calculate the values of BFG, DGCT, DGLT and D in our scenarios, we calculated a primary deficit. This supposed deducting interest paid on long and short term debt, which we estimated assuming 1/ that the long term debt in 1913 paid a 3\% rate ; 2/ that every year's debt increase after 1913 paid that year's yield of the 3\% rente, plus half a percentage point; and 3/ that short term debt always paid 5\% interest. Knowing the deficit (BFG), we could calculate its value in our scenario, first by deflating its amount by the ratio of British to French prices (based on the assumed stabilization year), then by adding the value of new taxes, and the value of the consolidation of Banque de France loans (e.g. 3 billion a year, plus the deflated value of the actual growth of those loans, which should have been financed by the budget in our scenario). Adding to this hypothetical primary deficit the interest paid on the previous year's long term and short term debt allows us to calculate the hypothetical deficit BFG, and then to calculate $\mathrm{D}_{\mathrm{t}}$ using $\mathrm{D}_{\mathrm{t}-1}$. Our hypothesis on the evolution of short term debt (stagnation in 1919, consolidation of 10 billion a year from 1920 on) allows us to calculate the long term debt (DGLT=D-DGCT). Using both, we calculate the amount of interest paid, which enters in the increase of $\mathrm{D}$. This allows to take into account both the consolidation of short term debt and the decrease in budget deficits (thanks to new taxes) in the calculation of interest on the long term debt.

\footnotetext{
${ }^{29}$ Nevertheless, we smoothed the evolution of these variations in the three years 1919-1921 (instead of $-20,+6.7,-16.7$, we put a constant -10 every year) in order to eliminate apparent shocks resulting only from problems in these series.
} 
Then, we calculate our hypothetical primary deficit from our assumptions on short term debt (DGCT), interest rates paid on both long and short term debts, the evolution of government expenditures and existing ressources, and the creation of new taxes. Then, the budget deficit at $t$ equals:

Deft $=$ INTLTt + INTSTt + PrimDeft - NTt - AV

where Def is the deficit, INTLT interest paid on long term debt, INTST interest on short term debt and PrimDef is the primary budget deficit (PrimDef $=\mathrm{G}-\mathrm{T}$ ) (G represents public expenditures other than interest payments and $\mathrm{T}$ taxes). NT are new taxes ${ }^{30} . \mathrm{AV}$ is the variation of Banque de France loans (which provided a non-monetary resource, or which reimbursement increased the deficit. The evolution of the debt follows from that of the deficits.

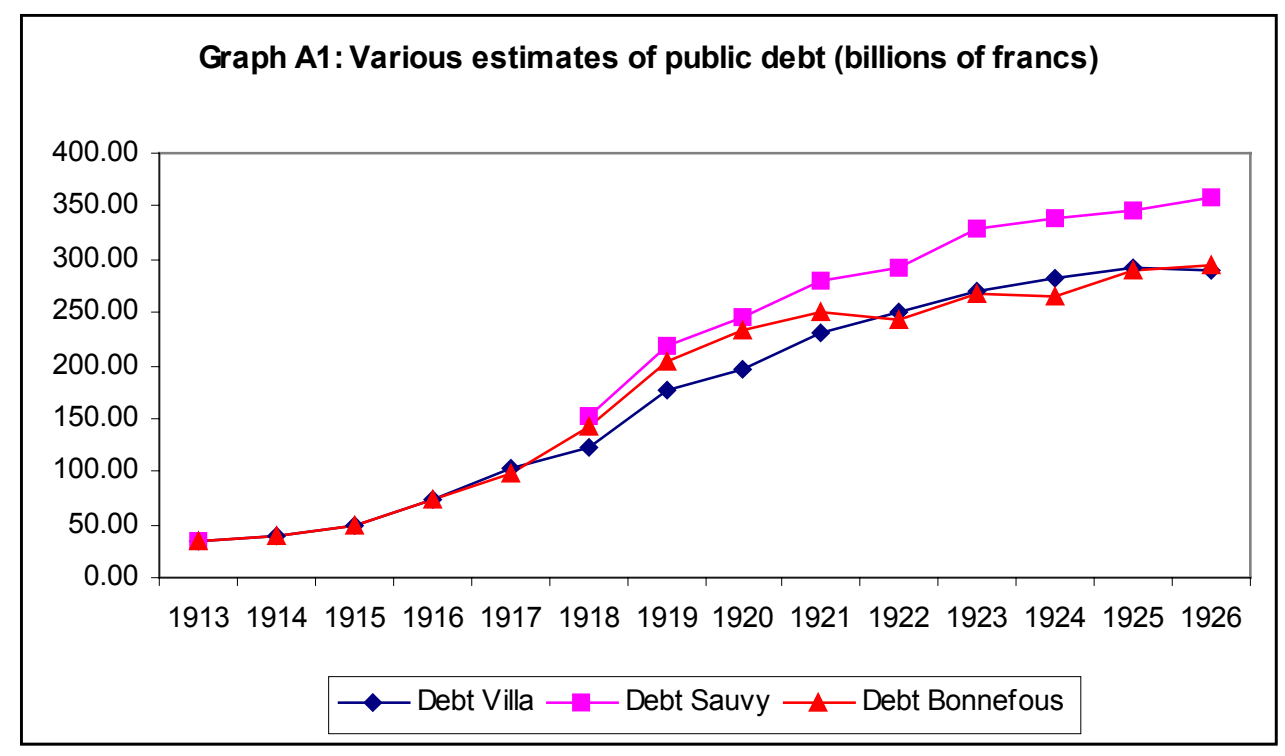

\footnotetext{
${ }^{30}$ What we call here new taxes are taxes above those actually created in the scenario above. Actual taxes were also raised significantly during the 1920 's.
} 


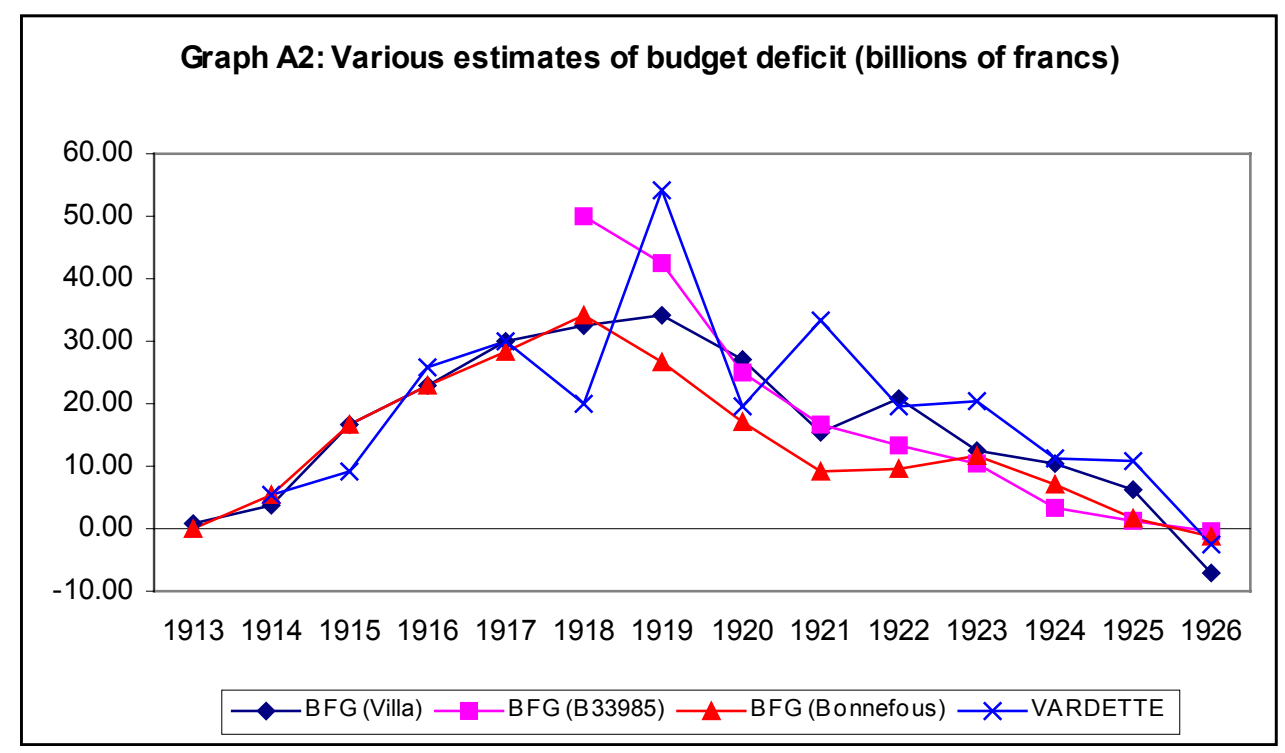

